\title{
Evaluation of critical storm duration rainfall estimates used in flood hydrology in South Africa
}

\author{
OJ Gericke* and JA du Plessis \\ Department of Civil Engineering, University of Stellenbosch, P/Bag X1, MATIELAND 7602, South Africa
}

\begin{abstract}
Design rainfall comprises of a depth and duration associated with a given probability of exceedance or return period. The purpose of the study was to evaluate and compare the methods used in flood hydrology to estimate depth-duration-frequency (DDF) relationships of design rainfall in South Africa based on the critical storm duration or time of concentration $\left(T_{C}\right)$ of a catchment. The influence of the type of rainfall, areal and temporal distribution of rainfall were also investigated to establish if a relationship exists between the catchment area, $T_{C}$ and areal reduction factors (ARFs). The DDF relationships based on the least-square regression analyses of Log-Extreme Value Type 1 distributions, the modified Hershfield equation, the regionalised South African Weather Service (SAWS) $n$-day design rainfall data and the Regional Linear Moment Algorithm and Scale Invariance (RLMA\&SI) approach were compared in 3 distinctive $T_{C}$-ranges. The results showed that the RMLA\&SI approach can be considered as the preferred DDF relationship in future design flood estimations. The results also showed that a direct relationship exists between the catchment area and $T_{C}$, thus ARFs can be explicitly expressed in terms of only the catchment area.
\end{abstract}

Keywords: Rainfall, depth-duration-frequency, time of concentration, areal reduction factors, design flood

\section{Introduction}

Design rainfall comprises of a depth and duration associated with a given probability of exceedance or return period. Short and long duration design rainfall estimations can either be based on point or regionalised data. Rainfall durations less than $24 \mathrm{~h}$ are generally classified as short, while long durations typically range from 1 to 7 days (Smithers and Schulze, 2004).

Several regional and national scale studies in South Africa based on short durations and point data were conducted between 1945 and 2001. The studies focusing on long durations based on daily point rainfall data included studies done by the SAWB (South African Weather Bureau) (1956), Schulze (1980), Adamson (1981), Pegram and Adamson (1988) and Smithers and Schulze (2000b). Smithers and Schulze (2000a; 2000b) also used a regionalised approach in an attempt to increase the reliability of the design values at gauged sites, as well as for the estimation of design values at ungauged sites (Smithers and Schulze, 2003).

Irrespective of whether a single site or regional approach is followed, the design rainfall depth to be used in design flood estimation, especially in the deterministic methods, must be based on the critical storm duration or time of concentration $\left(T_{C}\right)$ of a catchment.

This paper attempts to provide preliminary insight into the applicability of the various methods used in South Africa to estimate design rainfall. The purpose of the study is discussed and explained in the next section, followed by an overview of the study area's spatial distribution and characteristics. Thereafter, the methods used in South Africa to estimate $T_{C}$, depth-duration-frequency (DDF) relationships and areal

\footnotetext{
* To whom all correspondence should be addressed.

푱 +27 51 507-3516; fax: +27 51 507-3254; e-mail: igericke@cut.ac.za

Received 8 December 2010; accepted in revised form 5 September 2011.
}

reduction factors (ARFs) are reviewed in detail. The methodologies involved in assessing the paper's purpose and objectives are then expanded on in detail, followed by the results, discussion, conclusions and recommendations.

\section{Purpose of study}

The purpose of the study was to evaluate the methods used in flood hydrology to estimate DDF relationships of design rainfall in South Africa, based on the critical storm duration or $T_{C}$ of a catchment, in 3 distinctive $T_{C}$-ranges. The focus was not necessarily to establish the best method; the results from the different methods were compared to highlight any inherent shortcomings present in these methods. In catchments where $T_{C}$ exceeded $24 \mathrm{~h}$, the different methods were compared to the regionalised South African Weather Service (SAWS) daily design rainfall database (after Smithers and Schulze, 2000b). For $T_{C}$ less than $24 \mathrm{~h}$, the Regional Linear Moment Algorithm and Scale Invariance (RLMA\&SI) approach for estimating design rainfall (after Smithers and Schulze, 2000a) was used as the reference method. These 2 reference methods were used to assess the relative accuracy of all the other available methods. The influences of the type of rainfall and point-to-point differences in the areal and temporal distribution of rainfall were also investigated. This was done to establish whether a relationship exists between the catchment area, $T_{C}$ and ARFs.

Firstly, it was hypothesised that runoff depends not only on the amount and intensity of rainfall, but is also affected by the duration, size, uniformity, velocity and direction of a storm passing over a catchment. Secondly, it was hypothesised that flood-causing storms have durations just long enough to allow runoff from all parts of the catchment to contribute simultaneously to the flood peak; hence the relationship between the critical duration of a storm and $T_{C}$. Thirdly, it was hypothesised that flood-producing storm rainfall is almost never evenly distributed, both in time and space, over an area. Lastly, it was hypothesised that water engineers and other consultants 


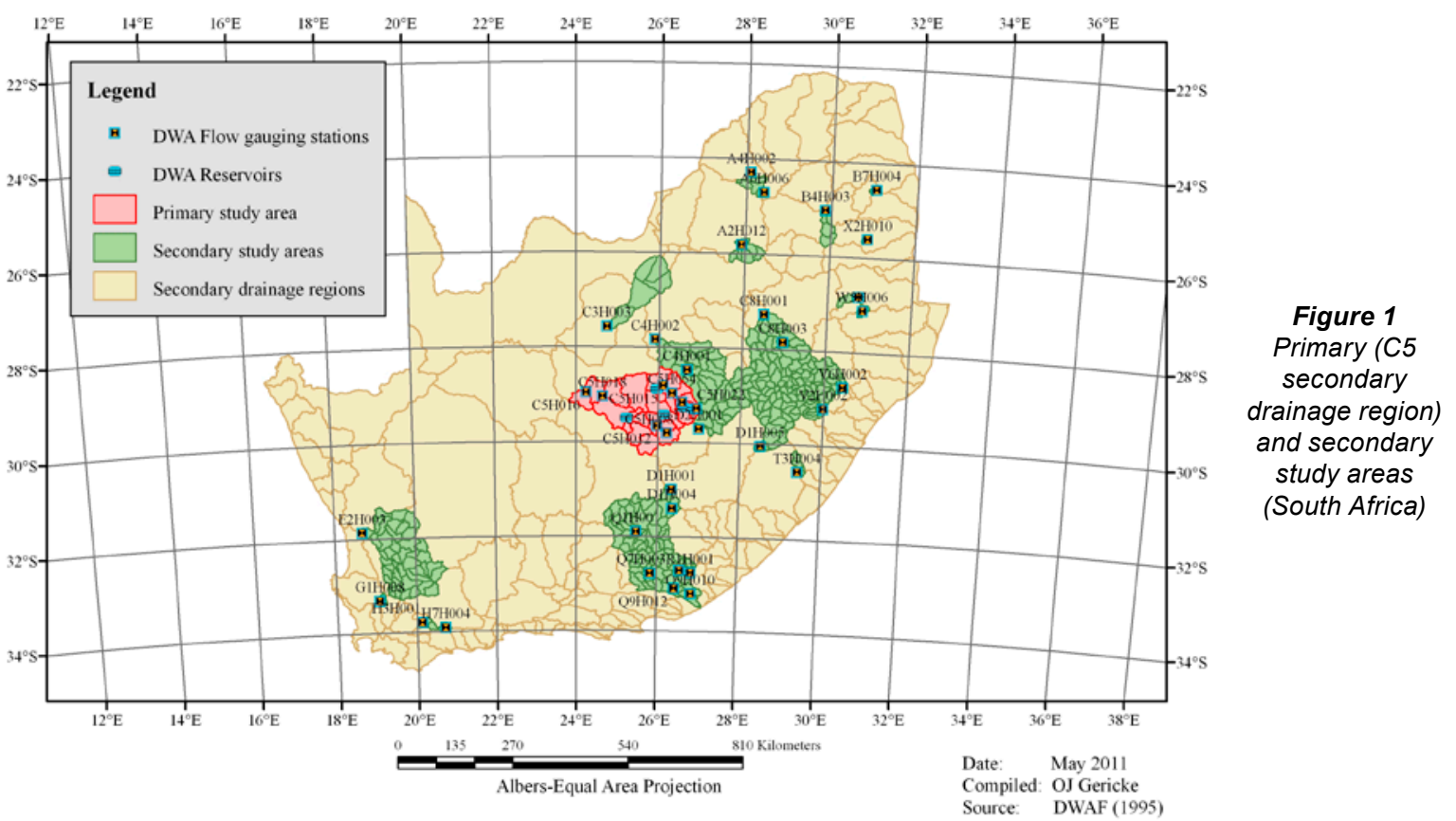

(not necessarily hydrologists) tend to use only well-known and simplified DDF relationships to estimate design rainfall depths, irrespective of whether numerical or graphical procedures are used. This is probably due to the direct statistical analysis that needs to be conducted to convert daily observed point rainfall to a design rainfall depth associated with $T_{C}$, as well as the uncertainty of the relative applicability thereof and whether the rainfall magnitude-frequency relationships will be satisfactorily accommodated in these alternatives. In addition, Weddepohl (1988), highlighted that the malfunctioning of rainfall gauges, the spatial density and distribution of rainfall gauges, sporadic rainfall events as opposed to the continuous digitised data in use, length of available records and the presence of outliers are all problems inherently contributing to errors in rainfall and subsequently the tendency to use existing DDF relationships to estimate design rainfall in South Africa.

\section{Study areas}

The primary study area covers $34795 \mathrm{~km}^{2}$, between $28^{\circ} 25^{\prime}$ and $30^{\circ} 17^{\prime}$ 'South and $23^{\circ} 49^{\prime}$ and $27^{\circ} 00^{\prime}$ 'East and comprises the C5 secondary drainage region in South Africa. The Riet River and Modder River catchments are the 2 tertiary catchments in the main study area. The area is characterised by the following land uses: $99.1 \%$ rural, $0.7 \%$ urbanised and $0.2 \%$ water bodies (CSIR, 2001). The natural vegetation is dominated by Grassland of the interior plateau, False Karoo and Karoo (light bush). Cultivated land is the largest human-induced vegetation alteration in the rural areas, while residential and suburban areas dominate the urban areas. The topography is gentle (slopes between $2.4 \%$ and $5.5 \%$ ) and water tends to pool easily, thus influencing the attenuation and translation of floods. The mean annual precipitation (MAP) is $424 \mathrm{~mm}$, ranging from $275 \mathrm{~mm}$ in the west to $685 \mathrm{~mm}$ in the east. It is characterised as highly variable and unpredictable. The rainy season is from early September to mid-April, with a dry winter (Midgley et al., 1994).

To enhance the understanding of the results obtained from this study, as well as to illustrate the relevance thereof in a South African context in different climatic regions,
29 additional catchments, ranging from $28 \mathrm{~km}^{2}$ to $29328 \mathrm{~km}^{2}$, were randomly selected in South Africa as secondary study areas. The results (catchment areas and $T_{C}$ ) from previous research conducted by Petras and Du Plessis (1987) and Parak and Pegram (2006) were used as default input parameters to evaluate the current DDF relationships in use.

The location of the primary and secondary study areas is shown in Fig. 1.

\section{Review of Critical Storm Duration Rainfall}

The following provides a review of the methods used in South Africa to estimate $T_{C}$, DDF relationships and ARFs.

\section{Time of concentration}

$T_{C}$ (Eq. (1)) can be defined as the time required for runoff, as a result of rainfall with a uniform areal and temporal distribution, to contribute to the peak discharge at the catchment outlet. Thus, the time required for a water particle to travel from the catchment boundary along the longest watercourse to the catchment outlet (Rooseboom et al., 1993; SANRAL, 2006). In determining $T_{C}$, overland flow and/or flow in defined watercourses and/or artificial/man-made canals (urban areas) can occur.

$$
T_{C}=T_{C 1}+T_{C 2}+T_{C 3}
$$

where:

$T_{C}=$ total time of concentration (h)

$T_{C l}=$ time of concentration for overland flow (h), as shown in Eq. (2)

$T_{C 2}=$ time of concentration for flow in defined watercourses (h), as shown in Eq. (3)

$T_{C 3}=$ time of concentration for flow in artificial/man-made canals (h), as shown in Eq. (4)

Overland flow occurs in small, relatively flat catchments or in the upper reaches of a catchment, where there is no clearly defined watercourse. Runoff occurs in the form of thin layers of 


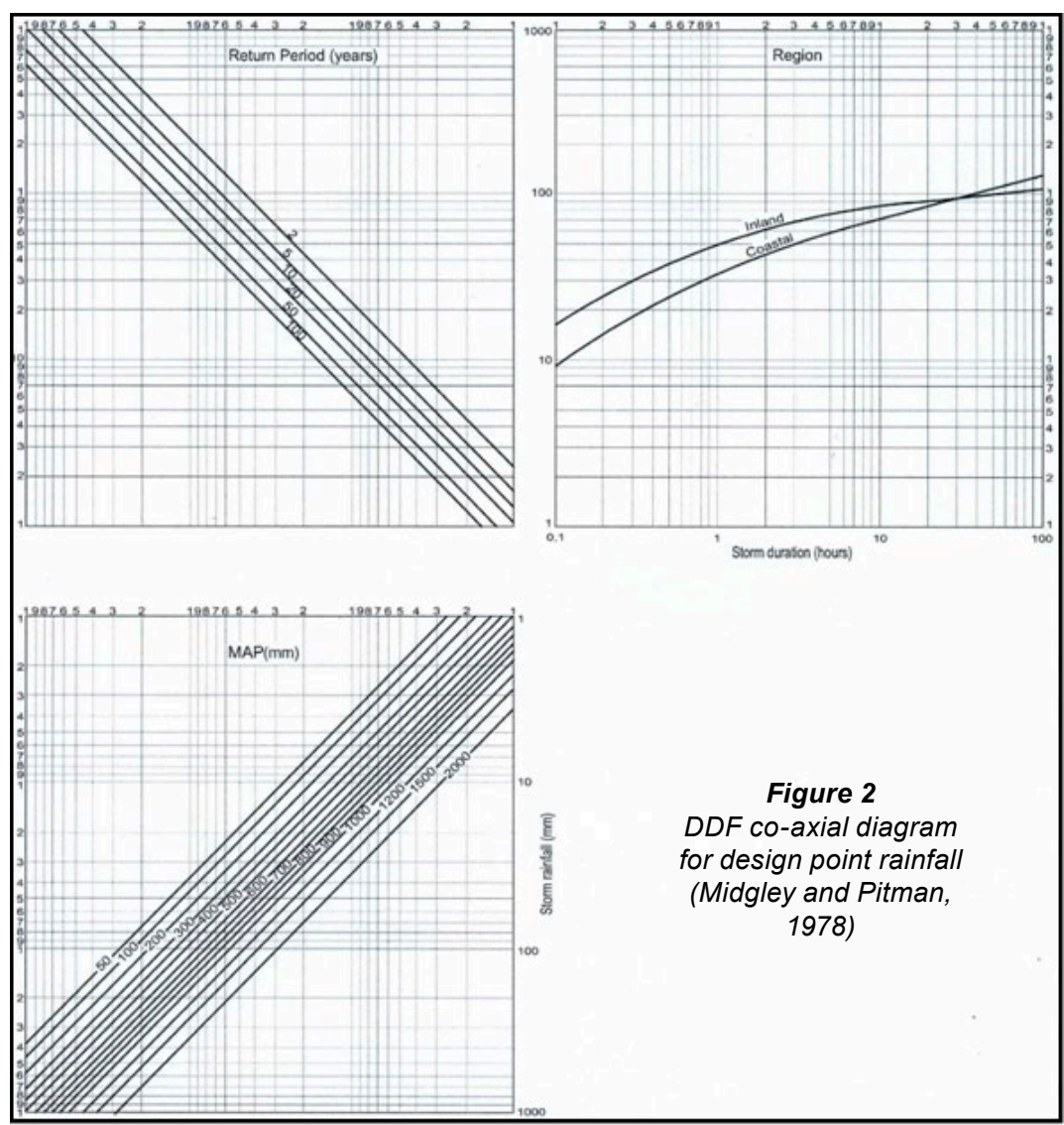

water flowing slowly over the surface. The Kerby equation (Eq. (2)) is applicable to overland flow conditions (Rooseboom et al., 1993; SANRAL, 2006).

$$
T_{C l}=0.604\left(\frac{r L}{\sqrt{\frac{H}{1000 L}}}\right)^{0.467}
$$

where:

$H=$ height difference along flow path (m)

$L=$ hydraulic length of flow path $(\mathrm{km})$

$r \quad$ roughness coefficient.

The roughness coefficient $(r)$ depends on the land use or cover along the flow path, and typically varies between 0.02 (paved areas) to 0.8 (thick grass cover) (SANRAL, 2006). It is similar to Manning's $n$-value and, according to McCuen (2005), representative roughness coefficient values can be estimated by selecting a basic roughness coefficient value followed by a 5-step correction process, whereby the coefficients are corrected for flow path irregularities and variations, presence of obstructions, vegetation differences and flow path meandering.

Channel flow occurs in a defined watercourse. The United States Department of Agriculture Soil Conservation Service (USDA-SCS) recommends the use of Eq. (3), while Kirpich (1940) recommends the use of Eq. (4) to determine $T_{C}$ in a natural, defined watercourse.

$$
\begin{aligned}
& T_{C 2}=\left(\frac{0.87 L^{2}}{1000 S_{\text {Avg }}}\right)^{0.385} \\
& T_{C 2}=0.0633\left(\frac{L^{2}}{S_{\text {Avg }}}\right)^{0.385}
\end{aligned}
$$

where:

$$
\begin{aligned}
L= & \begin{array}{l}
\text { length of longest watercourse } \\
(\mathrm{km})
\end{array} \\
S_{A v g}= & \begin{array}{l}
\text { average main watercourse slope } \\
\left(\mathrm{m} \cdot \mathrm{m}^{-1}\right)
\end{array}
\end{aligned}
$$

In urban areas or artificial/man-made canals, $T_{C}$ must be based on the calculated flow velocity estimated using the Chézy or Manning equations. Permissible velocity ranges, based on the material used, must be adhered to (Rooseboom et al., 1993; SANRAL, 2006) and $T_{C}$ for flow in artificial/man-made canals can be estimated using Eq. (5) (SANRAL, 2006).

$$
T_{C 3}=\left(\frac{L}{3600 \bar{v}}\right)
$$

where:

$$
\begin{aligned}
\mathrm{L}= & \text { length of artificial } / \text { man-made } \\
& \text { canal }(\mathrm{m}) \\
\bar{v}= & \text { average velocity }\left(\mathrm{m} \cdot \mathrm{s}^{-1}\right)
\end{aligned}
$$

\section{DDF relationship based on Log- Extreme Value Type 1 (LEV1) distributions}

Midgley and Pitman (1978), referred to as M\&P in this paper, developed a DDF coaxial diagram (Fig. 2) in which the design point rainfall is a function of the critical storm duration $\left(T_{C}\right)$, regional location (regional factors), probability of exceedance (frequency factors) and MAP.

According to Schulze (1984), there are some anomalies in the database used, since the LEV1 distribution estimated physically impossible rainfall values in some cases. Sinske (1982) emphasised the practical difficulties of using the coaxial diagram and on deciding whether a summer/inland or winter/coastal estimate is applicable to the site of concern. Adamson (1981) indicated that storms shorter than $2 \mathrm{~h}$ in duration are likely to be independent of the MAP. Least-square regression analyses were used to derive relationships from the data used by Midgley and Pitman (1978; as cited in Alexander, 2001). These relationships are provided in Eqs. (6) to (9):

$$
\begin{aligned}
& P=\left(I_{W, S}\right)\left(T_{C}\right)\left(M_{F}\right)(F) \\
& I_{W}=\frac{122.8}{\left(1+4.779 T_{C}\right)^{0.7372}} \\
& I_{S}=\frac{217.8}{\left(1+4.164 T_{C}\right)^{0.8832}} \\
& M_{F}=\frac{(18.79+0.17 M A P)}{100}
\end{aligned}
$$

where:

$$
\begin{aligned}
& F \quad=\text { frequency factor } \\
& I_{S} \quad=\text { rainfall intensity in summer/inland regions }\left(\mathrm{mm} \cdot \mathrm{h}^{-1}\right) \\
& I_{W} \quad=\text { rainfall intensity in winter/coastal regions }\left(\mathrm{mm} \cdot \mathrm{h}^{-1}\right) \\
& M A P=\text { mean annual precipitation }(\mathrm{mm}) \\
& M_{F} \quad=\text { MAP factor } \\
& P \quad=\text { rainfall depth }(\mathrm{mm}) \\
& T_{C} \quad=\text { time of concentration }(\mathrm{h})
\end{aligned}
$$


The frequency factors $(F)$, based on the relationship between the design rainfall depths and various return periods, are listed in Table 1.

\begin{tabular}{|c|c|}
\hline \multicolumn{2}{|c|}{ Table 1 } \\
$\begin{array}{c}\text { Frequency factors (Midgley and } \\
\text { Pitman, 1978; Alexander, 2001) }\end{array}$ \\
\hline $\begin{array}{c}\text { Return period (T, } \\
\text { years) }\end{array}$ & $\begin{array}{c}\text { Frequency factors } \\
\text { (F) }\end{array}$ \\
\hline 2 & 0.47 \\
\hline 5 & 0.64 \\
\hline 10 & 0.81 \\
\hline 20 & 1.00 \\
\hline 50 & 1.30 \\
\hline 100 & 1.60 \\
\hline 200 & 1.80 \\
\hline
\end{tabular}

\section{DDF relationship based on the Technical Report 102 (TR102) daily rainfall data}

The 1, 2, 3 and 7-day extreme design rainfall depths for return periods of 2, 5, 10, 20, 50, 100 and 200 years were estimated by Adamson (1981) using approximately 2400 rainfall stations. A censored Log-Normal (LN) distribution based on the Partial Duration Series (PDS) was used in this study to estimate the design rainfall depths at a single site. According to Adamson (1981), the daily rainfall depth recorded at fixed 24-h intervals can be converted to a continuous 24-h rainfall depth by making use of the relationship provided in Eq. (10). However, this approach is outdated and Smithers and Schulze (2000a) developed regionalised relationships for 15 relatively homogeneous rainfall regions in South Africa, with a national average of 1.21

$$
P_{24 h}=1.11 P_{1 \text { day }}
$$

where:

$$
\begin{array}{ll}
P_{24 h} & =24-\mathrm{h} \text { rainfall depth }(\mathrm{mm}) \\
P_{\text {l-day }} & =1 \text {-day rainfall depth }(\mathrm{mm})
\end{array}
$$

The computed ratios for the $T_{C}$ (hour) duration storm depth to that for $24 \mathrm{~h}$, for the summer/inland and winter/coastal rainfall regions, are listed in Table 2.

\begin{tabular}{|c|c|c|}
\hline \multicolumn{3}{|c|}{$\begin{array}{c}\text { Table 2 } \\
\text { Ratio of } \boldsymbol{T}_{c} \text { (hours) storm depth to 24 hour } \\
\text { storm depth (Adamson, 1981) }\end{array}$} \\
\hline $\boldsymbol{T}_{c}$ (hours) & $\begin{array}{c}\text { Summer/inland } \\
\text { region }\end{array}$ & $\begin{array}{c}\text { Winter/coastal } \\
\text { region }\end{array}$ \\
\hline 0.10 & 0.17 & 0.14 \\
\hline 0.25 & 0.32 & 0.23 \\
\hline 0.50 & 0.46 & 0.32 \\
\hline 1 & 0.60 & 0.41 \\
\hline 2 & 0.72 & 0.53 \\
\hline 3 & 0.78 & 0.60 \\
\hline 4 & 0.82 & 0.67 \\
\hline 5 & 0.84 & 0.71 \\
\hline 6 & 0.87 & 0.75 \\
\hline 8 & 0.90 & 0.81 \\
\hline 10 & 0.92 & 0.85 \\
\hline 12 & 0.94 & 0.89 \\
\hline 18 & 0.98 & 0.96 \\
\hline 24 & 1.00 & 1.00 \\
\hline \multicolumn{3}{|c|}{} \\
\hline
\end{tabular}

Converting daily design rainfall depths to durations longer than 1 day simply entails the conversion of fixed interval to continuous measurement (e.g.1 day to $24 \mathrm{~h}, 2$ days to $48 \mathrm{~h}$ ), and interpolating between the different duration (h) rainfall depths as given in Table 3 . However, this simple approach is outdated and no literature is available as to how these ratios were derived. In the next section, the regional approach proposed by Smithers and Schulze (2000b) is discussed as the preferred design rainfall database to TR102.

\begin{tabular}{|c|c|c|}
\hline \multicolumn{3}{|c|}{$\begin{array}{c}\text { Table 3 } \\
\text { Conversion of daily to hourly rainfall } \\
\text { (Van der Spuy and Rademeyer, 2008) }\end{array}$} \\
\cline { 1 - 2 } Duration & $\begin{array}{c}\text { Conversion } \\
\text { factor }\end{array}$ \\
\cline { 1 - 2 } From (days) & To (hours) & 1.11 \\
\hline 1 & 24 & 1.07 \\
\hline 2 & 48 & 1.05 \\
\hline 3 & 72 & 1.04 \\
\hline 4 & 96 & 1.03 \\
\hline 5 & 120 & 1.02 \\
\hline 7 & 168 & 1 \\
\hline$>7$ & $>168$ & \\
\hline
\end{tabular}

\section{DDF relationship based on the regionalised SAWS daily rainfall data}

Smithers and Schulze (2000b) conducted direct statistical analyses based on the General Extreme Value (GEV) probability distribution, at 1789 rainfall stations with at least 40 years of record, to estimate the 1-day design rainfall values in South Africa. This was followed by a regionalisation process (based on Linear-Moments) and establishment of 78 relatively homogeneous rainfall regions and associated index values derived from at-site data.

Quantile growth curves, representative of the ratio between design rainfall depth and an index storm to return period, were developed for each of the homogeneous rainfall regions and storm durations of 1 to 7 days. These regionalised growth curves and the at-site index values were then used to estimate design rainfall depths at 3946 rainfall stations in South Africa (Smithers and Schulze, 2000b).

In this paper, the 3946 rainfall stations are collectively referred to as the Regional L-Moment Algorithm SAWS $n$-day design point rainfall database (RLMA-SAWS), since the majority $(82.2 \%)$ of the daily rainfall stations used, were contributed by the SAWS. The remaining daily rainfall data were provided by the Institute for Soil, Climate and Water (ISCW), the South African Sugar Association Experiment Station (SASEX) and private individuals (Smithers and Schulze, 2000b).

\section{DDF relationship based on the modified Hershfield equation}

Alexander (2001) proposed that the modified Hershfield equation (Eq. (11)) must be used to calculate the DDF relationships for durations less than $6 \mathrm{~h}$. For rainfall durations longer than $6 \mathrm{~h}$ and less than $24 \mathrm{~h}$, Alexander (2001) recommends linear interpolation between Eq. (11) and the 1-day design point rainfall depth from TR102 (Adamson, 1981). If $T_{C}$ exceeds $24 \mathrm{~h}$, then linear interpolation between the $n$-day design point rainfall depth values must be used. In this paper, the RLMASAWS database (after Smithers and Schulze, 2000b) was used 
instead of TR102, since this database has \pm 20 years more data at 3946 rainfall stations.

$P=1.13(0.41+0.64 \ln T)\left(-0.11+0.27 \ln \left(60 T_{C}\right)\right)\left(0.79 M^{0.69} R^{0.20}\right)$

where:

$M=2$-year mean of the annual daily maxima rainfall $(\mathrm{mm})$

$P=$ rainfall depth (mm)

$R=$ average number of days per year on which thunder was heard

$T=$ return period (years)

$T_{C}=$ time of concentration (h)

\section{DDF relationship based on a regional scale invariant approach}

Regional approaches are well established in frequency analysis and various different techniques are available. The use of the RLMA approach by Smithers and Schulze (2000b), to estimate long duration design rainfall, was highlighted in a previous section. The same approach was followed to estimate short duration $(<24 \mathrm{~h})$ design rainfall in South Africa, but it was based on digitised rainfall data from 172 stations which had at least 10 years of data (Smithers and S chulze, 2003; 2004). A scale invariance approach, where the mean Annual Maximum Series (AMS) for any duration can be estimated by firstly estimating the mean 1-day AMS at a single site by regional regression, followed by scaling either the mean AMS for durations shorter or longer than 1 day, respectively, from the $24 \mathrm{~h}$ and 1 day values, were used in conjunction with RLMA. This application is referred to as the Regional Linear Moment Algorithm and Scale Invariance (RLMA\&SI) approach. A software program, 'Design Rainfall Estimation in South Africa' was developed in 2003 to facilitate the estimation of design rainfall depths at a spatial resolution of 1-arc minute, for any location in South Africa, based on the RLMA\&SI approach, for durations ranging from 5 min to 7 days and for return periods of 2 to 200 years (Smithers and Schulze, 2003; 2004).

\section{Areal reduction factor}

Design point rainfall estimates are only representative for a limited area, and for larger areas the areal average design rainfall depths or intensities are likely to be less than the maximum observed point rainfall depths or intensities. The estimation of ARFs is concerned with the relationship between the design point and areal rainfall; in other words, ARFs are used to convert design point rainfall depth/intensity to average areal design rainfall depth/intensity for a given duration and catchment area (Alexander, 2001).

In small catchment areas, of less than $800 \mathrm{~km}^{2}$, the ARF is mainly a function of the area and design point rainfall intensity, since the relationship between rainfall intensity and the infiltration rate of the soil is predominant. In medium to large catchment areas, up to $30000 \mathrm{~km}^{2}$, the ARF is mainly a function of the area and storm duration, since the quantity of rainfall relative to the number of storage areas is of great importance. In both cases, the ARF decreases in value with an increase in area and is independent of the return period and geographical location. These relationships are clearly evident from the ARF graphs included in the Drainage Manual (SANRAL, 2006). These graphs are based on a variable location, stormcentred analysis, as conducted by the HRU (1972). However, this approach posed conceptual problems when applied to a geographically-fixed catchment and the use of a correction factor was suggested (Alexander, 2001). In response, Alexander (1980) developed a geographically-centred ARF relationship based on the ARFs contained in the United Kingdom Flood Studies Report (UK FSR) (NERC, 1975).

This developed ARF relationship (Eq. (12)), as a function of the catchment area and response time in terms of $T_{C}$, resulted in slightly more conservative results when compared to the UK FSR and United States Weather Bureau (USWB) values (Alexander, 2001).

$$
A R F=\left(90000-12800 \ln A+9830 \ln \left(60 T_{C}\right)\right)^{0.4}
$$

$$
\begin{aligned}
& \text { where: } \\
& \qquad \begin{aligned}
A & =\text { catchment area }\left(\mathrm{km}^{2}\right) \\
A R F & =\text { areal reduction factor }(\%) \\
T_{C} & =\text { time of concentration }(\mathrm{h})
\end{aligned}
\end{aligned}
$$

In Eq. (12) the ARF relationship accommodates severe storm mechanisms producing very high intensity rainfall with cell core areas exceeding $10 \mathrm{~km}^{2}$ and durations exceeding $10 \mathrm{~min}$. Estimates of shorter duration rainfall based on extrapolation from longer durations are unreliable when viewed in the light of the storm mechanisms which produce high-intensity rainfall for durations less than 10 min (Alexander, 2001).

\section{Methodology}

This section provides the detailed methodology followed during this study and is based on the theoretical methods reviewed in the previous section.

\section{Averaging of rainfall depth}

The arithmetic mean, Thiessen polygon and isohyetal methods were used to convert the point design rainfall depths at 185 rainfall stations (from RLMA-SAWS database) to an average design rainfall depth over the main study area (C5 secondary drainage region). The details (station number, record length, MAP and Thiessen polygon area) of the above-mentioned 185 rainfall stations are listed in Table 4 . The same procedure was also followed in 12 quaternary catchments within the main study area. The 29 secondary study areas were analysed similarly, but without using the isohyetal method. A flow gauging station from the Department of Water Affairs (DWA) is situated at the outlet of all the catchments used in the study. The flow gauging station numbers were therefore used as the catchment identifier or descriptor for easy reference.

The Areal Rain extension in ArcView 3.2a was used to generate Thiessen polygons representative of the averaged design rainfall depths for a particular area (catchment) from design point rainfall measurements. The boundary of the resultant Thiessen polygons was selected in each case either by the applicable quaternary catchments (polygon feature classes) or by a buffered group of rainfall stations (point feature classes). The latter option provides an alternative that allows the user to include rainfall stations located outside the catchment boundary. The rainfall station number field in the attribute table of the point feature class (rainfall stations) was used to identify points and rainfall. The attribute table was then automatically updated; fields (Thiessen area, total area, weighted area, Thiessen and areal rainfall) were added with the geometry (area) being calculated. These attribute tables were 


\begin{tabular}{|c|c|c|c|c|}
\hline & $\begin{array}{r}185 \text { RLMA } \\
\text { in the }\end{array}$ & $\begin{array}{l}\text { Table } 4 \\
\text { VS rainf } \\
\text { lary stu }\end{array}$ & $\begin{array}{l}\text { tions } \\
\text { a (C5 }\end{array}$ & \\
\hline Number & $\begin{array}{l}\text { Rainfall } \\
\text { station }\end{array}$ & $\begin{array}{l}\text { Record } \\
\text { length } \\
\text { (years) }\end{array}$ & $\begin{array}{l}\text { MAP } \\
(\mathrm{mm})\end{array}$ & $\begin{array}{c}\text { Thiessen } \\
\text { polygon } \\
\text { area }\left(\mathrm{km}^{2}\right)\end{array}$ \\
\hline 1 & $0201361 \mathrm{~W}$ & 86 & 414 & 140.7 \\
\hline 2 & $0201370 \mathrm{~W}$ & 42 & 435 & 2279 \\
\hline 3 & $0201373 \mathrm{~W}$ & 53 & 453 & 1434 \\
\hline 4 & $0201482 \mathrm{~W}$ & 86 & 414 & 108.8 \\
\hline 5 & $0201492 \mathrm{~W}$ & 43 & 453 & 129.0 \\
\hline 6 & $0201637 \mathrm{~W}$ & 37 & 340 & 123.9 \\
\hline 7 & $0201756 \mathrm{~W}$ & 28 & 361 & 81.7 \\
\hline 8 & $0201843 \mathrm{~W}$ & 29 & 382 & 147.6 \\
\hline 9 & $0228571 \mathrm{~W}$ & 68 & 332 & 171.5 \\
\hline 10 & $0228725 \mathrm{~W}$ & 52 & 314 & 223.6 \\
\hline 11 & $0228783 \mathrm{~W}$ & 56 & 334 & 133.9 \\
\hline 12 & $0229124 \mathrm{~W}$ & 59 & 370 & 178.2 \\
\hline 13 & $0229215 \mathrm{~W}$ & 43 & 366 & 176.6 \\
\hline 14 & $0229344 \mathrm{~W}$ & 52 & 401 & 190.8 \\
\hline 15 & $0229555 \mathrm{~W}$ & 51 & 420 & 75.8 \\
\hline 16 & $0229556 \mathrm{~W}$ & 33 & 422 & 109.7 \\
\hline 17 & $0229571 \mathrm{~W}$ & 50 & 368 & 172.7 \\
\hline 18 & 0229579W & 40 & 398 & 210.1 \\
\hline 19 & $0229629 \mathrm{~W}$ & 47 & 405 & 209.0 \\
\hline 20 & $0229654 \mathrm{~W}$ & $\frac{41}{36}$ & 374 & $\frac{209.0}{178.6}$ \\
\hline 21 & $0229723 \mathrm{~W}$ & 47 & 368 & 158.5 \\
\hline 22 & $0229737 \mathrm{~W}$ & 99 & 414 & 138.4 \\
\hline 23 & $0229862 \mathrm{~W}$ & 37 & 384 & 115.3 \\
\hline 24 & $0230011 \mathrm{~W}$ & 54 & 426 & 194.9 \\
\hline 25 & $0230027 \mathrm{~W}$ & 81 & 466 & 220.9 \\
\hline 26 & $0230048 \mathrm{~W}$ & 42 & 376 & 124.1 \\
\hline 27 & $0230073 \mathrm{~W}$ & 76 & 419 & 48.2 \\
\hline 28 & $0230074 \mathrm{~W}$ & 24 & 395 & 52.7 \\
\hline 29 & $0230210 \mathrm{~W}$ & 34 & 395 & 286.1 \\
\hline 30 & $0230254 \mathrm{~W}$ & 39 & 359 & 178.2 \\
\hline 31 & $0230349 \mathrm{~W}$ & 27 & 409 & 194.9 \\
\hline 32 & $0230363 \mathrm{~W}$ & 41 & 275 & 342.9 \\
\hline 33 & $0230466 \mathrm{~W}$ & 31 & 389 & 233.2 \\
\hline 34 & $0230542 \mathrm{~W}$ & 44 & 384 & 181.0 \\
\hline 35 & $0230566 \mathrm{~W}$ & 39 & 368 & 147.0 \\
\hline 36 & $0230598 \mathrm{~W}$ & 30 & 410 & 79.1 \\
\hline 37 & $0230764 \mathrm{~W}$ & 91 & 427 & 244.4 \\
\hline 38 & $0230774 \mathrm{~W}$ & 62 & 431 & 186.8 \\
\hline 39 & $0230810 \mathrm{~W}$ & 93 & 408 & 118.8 \\
\hline 40 & $0230816 \mathrm{~W}$ & 75 & 489 & 265.2 \\
\hline 41 & $0231076 \mathrm{~W}$ & 44 & 386 & 180.0 \\
\hline 42 & $0231114 \mathrm{~W}$ & 35 & 431 & 422.3 \\
\hline 43 & $0231161 \mathrm{~W}$ & 49 & 406 & 128.2 \\
\hline 44 & $0231247 \mathrm{~W}$ & 35 & 463 & 120.9 \\
\hline 45 & $0231279 \mathrm{~W}$ & 93 & 479 & 80.2 \\
\hline 46 & $0231361 \mathrm{~W}$ & 64 & 459 & 139.4 \\
\hline 47 & $0231375 \mathrm{~W}$ & 47 & 403 & 241.1 \\
\hline 48 & $0231395 \mathrm{~W}$ & 71 & 454 & 146.2 \\
\hline 49 & $0231588 \mathrm{~W}$ & 37 & 443 & 237.7 \\
\hline 50 & $0231663 \mathrm{~W}$ & 26 & 496 & 112.4 \\
\hline 51 & $0231713 \mathrm{~W}$ & 56 & 479 & 362.4 \\
\hline 52 & $0231754 \mathrm{~W}$ & 55 & 516 & 111.8 \\
\hline 53 & $0231761 \mathrm{~W}$ & 31 & 564 & 191.0 \\
\hline 54 & $0232011 \mathrm{~W}$ & 41 & 530 & 129.1 \\
\hline 55 & $0232018 \mathrm{~W}$ & 86 & 420 & $\begin{array}{l}12.11 \\
97.7\end{array}$ \\
\hline 56 & $\frac{0252010 \mathrm{~W}}{0232123 \mathrm{~W}}$ & $\frac{00}{88}$ & 520 & $\frac{91.1}{127.0}$ \\
\hline 57 & $0232181 \mathrm{~W}$ & 58 & 555 & 96.2 \\
\hline 58 & $0232211 \mathrm{~W}$ & 88 & 555 & 40.1 \\
\hline 59 & $0232275 \mathrm{~W}$ & 94 & 585 & 102.4 \\
\hline 60 & $0232301 \mathrm{~W}$ & 38 & 488 & 74.0 \\
\hline 61 & $0232512 \mathrm{~W}$ & 35 & 599 & 98.5 \\
\hline 62 & $0256638 \mathrm{~W}$ & 78 & 293 & 389.5 \\
\hline 63 & $0257391 \mathrm{~W}$ & 66 & 332 & 1583.0 \\
\hline 64 & $0257845 \mathrm{~W}$ & 85 & 364 & 381.8 \\
\hline 65 & $0257878 \mathrm{~W}$ & 36 & 358 & 332.9 \\
\hline 66 & $0258079 \mathrm{~W}$ & 38 & 305 & 483.8 \\
\hline 67 & $0258157 \mathrm{~W}$ & 32 & 385 & 67.9 \\
\hline 68 & $0258164 \mathrm{~W}$ & 70 & 322 & 161.6 \\
\hline 69 & $0258182 \mathrm{~W}$ & 85 & 359 & 858.9 \\
\hline 70 & $0258213 \mathrm{~W}$ & 41 & 404 & 57.7 \\
\hline 71 & $0258218 \mathrm{~W}$ & 50 & 359 & 49.1 \\
\hline 72 & $0258306 \mathrm{~W}$ & 68 & 348 & 27.5 \\
\hline 73 & $0258335 \mathrm{~W}$ & 50 & 375 & 156.6 \\
\hline 74 & $0258339 \mathrm{~W}$ & 51 & 374 & 49.2 \\
\hline 75 & $0258380 \mathrm{~W}$ & 63 & 275 & 147.3 \\
\hline
\end{tabular}

\begin{tabular}{|c|c|c|c|c|}
\hline \multicolumn{5}{|c|}{ Table 4 (continued) } \\
\hline Number & $\begin{array}{l}\text { Rainfall } \\
\text { station }\end{array}$ & $\begin{array}{l}\text { Record } \\
\text { length } \\
\text { (years) }\end{array}$ & $\begin{array}{l}\text { MAP } \\
(\mathrm{mm})\end{array}$ & $\begin{array}{l}\text { Thiessen } \\
\text { polygon } \\
\text { area }\left(\mathrm{km}^{2}\right)\end{array}$ \\
\hline 76 & 0258399W & 51 & 325 & 33.2 \\
\hline 77 & $0258434 \mathrm{~W}$ & 51 & 363 & 90.0 \\
\hline 78 & $0258458 \mathrm{~W}$ & 98 & 376 & 115.6 \\
\hline 79 & $0258467 \mathrm{~W}$ & 51 & 349 & 101.8 \\
\hline 80 & $0258474 \mathrm{~W}$ & 34 & 313 & 128.2 \\
\hline 81 & $0258581 \mathrm{~W}$ & 56 & 342 & 197.7 \\
\hline 82 & $0258624 \mathrm{~W}$ & 63 & 338 & 129.9 \\
\hline 83 & $0258740 \mathrm{~W}$ & 51 & 350 & 115.4 \\
\hline 84 & $0258812 \mathrm{~W}$ & 70 & 349 & 129.6 \\
\hline 85 & $0258827 \mathrm{~W}$ & 44 & 360 & 179.4 \\
\hline 86 & $0258894 \mathrm{~W}$ & 99 & 450 & 145.0 \\
\hline 87 & $0259002 \mathrm{~W}$ & 45 & 363 & 127.3 \\
\hline 88 & $0259086 \mathrm{~W}$ & 25 & 359 & 189.3 \\
\hline 89 & $0259102 \mathrm{~W}$ & 31 & 371 & 155.2 \\
\hline 90 & $0259131 \mathrm{~W}$ & 30 & 392 & 109.1 \\
\hline 91 & $0259278 \mathrm{~W}$ & 67 & 414 & 211.3 \\
\hline 92 & $0259348 \mathrm{~W}$ & 71 & 369 & 378.2 \\
\hline 93 & $0259390 \mathrm{~W}$ & 29 & 408 & 239.6 \\
\hline 94 & $0259578 \mathrm{~W}$ & 57 & 426 & 154.3 \\
\hline 95 & $0259609 \mathrm{~W}$ & 49 & 399 & 141.3 \\
\hline 96 & $0259727 \mathrm{~W}$ & 94 & 411 & 144.6 \\
\hline 97 & $0259743 \mathrm{~W}$ & 64 & 309 & 272.9 \\
\hline 98 & $0259855 \mathrm{~W}$ & 43 & 463 & 118.7 \\
\hline 99 & $0259881 \mathrm{~W}$ & 54 & 433 & 105.5 \\
\hline 100 & $0259887 \mathrm{~W}$ & 49 & 457 & 98.5 \\
\hline 101 & $0260004 \mathrm{~W}$ & 89 & 449 & 98.4 \\
\hline 102 & $0260030 \mathrm{~W}$ & 80 & 374 & 238.3 \\
\hline 103 & $0260082 \mathrm{~W}$ & 33 & 448 & 126.3 \\
\hline 104 & $0260083 \mathrm{~W}$ & 33 & 424 & 172.5 \\
\hline 105 & $0260126 \mathrm{~W}$ & 32 & 454 & 199.8 \\
\hline 106 & $0260163 \mathrm{~W}$ & 74 & 461 & 127.8 \\
\hline 107 & 0260314W & 39 & 440 & 218.4 \\
\hline 108 & 0260519W & 66 & 471 & 367.2 \\
\hline 109 & $0260555 \mathrm{~W}$ & 50 & 516 & 181.2 \\
\hline 110 & $0260660 \mathrm{~W}$ & 47 & 459 & 140.8 \\
\hline 111 & $0260678 \mathrm{~W}$ & 88 & 478 & 213.1 \\
\hline 112 & $0260715 \mathrm{~W}$ & 36 & 373 & 253.3 \\
\hline 113 & $0260882 \mathrm{~W}$ & 56 & 495 & 336.0 \\
\hline 114 & $0261146 \mathrm{~A}$ & 86 & 479 & 250.9 \\
\hline 115 & $0261183 \mathrm{~W}$ & 95 & 484 & 276.0 \\
\hline 116 & $0261256 \mathrm{~W}$ & 36 & 325 & 248.0 \\
\hline 117 & $0261266 \mathrm{~W}$ & 36 & 519 & 176.9 \\
\hline 118 & $0261275 \mathrm{~W}$ & 60 & 570 & 50.0 \\
\hline 119 & $0261307 \mathrm{~W}$ & 25 & 537 & 51.4 \\
\hline 120 & $0261312 \mathrm{~W}$ & 63 & 538 & 103.5 \\
\hline 121 & $0261365 \mathrm{~W}$ & 73 & 558 & 43.7 \\
\hline 122 & $0261366 \mathrm{~W}$ & 39 & 563 & 7.0 \\
\hline 123 & $0261367 \mathrm{~W}$ & 46 & 552 & 7.0 \\
\hline 124 & $0261368 \mathrm{~W}$ & 88 & 545 & 10.9 \\
\hline 125 & $0261369 \mathrm{~W}$ & 47 & 613 & 39.7 \\
\hline 126 & $0261425 \mathrm{~W}$ & 46 & 553 & 45.5 \\
\hline 127 & 0261426W & 30 & 553 & 15.0 \\
\hline 128 & $0261516 \mathrm{~W}$ & 42 & 537 & 56.0 \\
\hline 129 & $0261517 \mathrm{~W}$ & 37 & 514 & 16.2 \\
\hline 130 & $0261523 \mathrm{~W}$ & 94 & 518 & 191.9 \\
\hline 131 & $0261548 \mathrm{~W}$ & 26 & 518 & 73.0 \\
\hline 132 & $0261597 \mathrm{~W}$ & 53 & 426 & 256.7 \\
\hline 133 & $0261722 \mathrm{~W}$ & 94 & 534 & 221.9 \\
\hline 134 & $0261733 \mathrm{~W}$ & 70 & 486 & 171.5 \\
\hline 135 & $0261750 \mathrm{~W}$ & 55 & 497 & 149.3 \\
\hline 136 & $0261789 \mathrm{~W}$ & 27 & 551 & 142.8 \\
\hline 137 & $0261890 \mathrm{~W}$ & 36 & 523 & 342.6 \\
\hline 138 & 0262129W & 70 & 516 & 143.5 \\
\hline 139 & $0262155 \mathrm{~W}$ & 32 & 473 & 132.7 \\
\hline 140 & $0262247 \mathrm{~W}$ & 24 & 566 & 113.6 \\
\hline 141 & $0262271 \mathrm{~W}$ & 28 & 435 & 140.5 \\
\hline 142 & $0262314 \mathrm{~W}$ & 54 & 526 & 250.4 \\
\hline 143 & $0262353 \mathrm{~W}$ & 52 & 530 & 296.5 \\
\hline 144 & $0262453 \mathrm{~W}$ & 24 & 548 & 183.9 \\
\hline 145 & $0262479 \mathrm{~W}$ & 94 & 554 & 125.6 \\
\hline 146 & $0262613 \mathrm{~W}$ & 76 & 590 & 242.2 \\
\hline 147 & $0262690 \mathrm{~W}$ & 47 & 548 & 115.3 \\
\hline 148 & $0262734 \mathrm{~W}$ & 43 & 649 & 70.4 \\
\hline 149 & $0262828 \mathrm{~W}$ & 30 & 686 & 147.2 \\
\hline 150 & 0290810W & 64 & 380 & 357.5 \\
\hline 151 & $0290887 \mathrm{~W}$ & 45 & 392 & 487.5 \\
\hline 152 & $0291075 \mathrm{~W}$ & 32 & 441 & 146.0 \\
\hline 153 & 0291148W & 90 & 397 & 70.0 \\
\hline
\end{tabular}




\begin{tabular}{|c|c|c|c|c|}
\hline \multicolumn{5}{|c|}{ Table 4 (continued) } \\
\hline Number & $\begin{array}{l}\text { Rainfall } \\
\text { station }\end{array}$ & $\begin{array}{l}\text { Record } \\
\text { length } \\
\text { (years) }\end{array}$ & $\begin{array}{l}\text { MAP } \\
(\mathrm{mm})\end{array}$ & $\begin{array}{l}\text { Thiessen } \\
\text { polygon } \\
\text { area }\left(\mathrm{km}^{2}\right)\end{array}$ \\
\hline 154 & 0291174W & 34 & 375 & 109.5 \\
\hline 155 & $0291178 \mathrm{~W}$ & 59 & 396 & 66.1 \\
\hline 156 & $0291231 \mathrm{~W}$ & 42 & 333 & 107.9 \\
\hline 157 & 0291313W & 44 & 431 & 242.4 \\
\hline 158 & $0291323 \mathrm{~W}$ & 29 & 404 & 100.3 \\
\hline 159 & $0291360 \mathrm{~W}$ & 44 & 403 & 196.8 \\
\hline 160 & $0291415 \mathrm{~W}$ & 46 & 394 & 209.2 \\
\hline 161 & $0291582 \mathrm{~W}$ & 39 & 449 & 225.2 \\
\hline 162 & 0291708W & 47 & 390 & 292.1 \\
\hline 163 & $0291758 \mathrm{~W}$ & 33 & 418 & 337.4 \\
\hline 164 & $0291899 \mathrm{~W}$ & 85 & 433 & 201.7 \\
\hline 165 & $0292051 \mathrm{~W}$ & 41 & 398 & 379.6 \\
\hline 166 & 0292089W & 36 & 430 & 162.8 \\
\hline 167 & $0292446 \mathrm{~W}$ & 35 & 438 & 509.0 \\
\hline 168 & $0292461 \mathrm{~W}$ & 90 & 432 & 576.3 \\
\hline 169 & $0292606 \mathrm{~W}$ & 40 & 455 & 155.5 \\
\hline 170 & $0292833 \mathrm{~W}$ & 47 & 453 & 435.5 \\
\hline 171 & $0293007 \mathrm{~W}$ & 66 & 453 & 446.7 \\
\hline 172 & $0293106 \mathrm{~W}$ & 71 & 471 & 301.5 \\
\hline 173 & $0293204 \mathrm{~W}$ & 61 & 478 & 293.7 \\
\hline 174 & 0293339W & 35 & 406 & 224.3 \\
\hline 175 & $0293403 \mathrm{~W}$ & 24 & 463 & 240.2 \\
\hline 176 & $0293514 \mathrm{~W}$ & 73 & 486 & 300.9 \\
\hline 177 & $0293568 \mathrm{~W}$ & 38 & 464 & 140.6 \\
\hline 178 & $0293597 \mathrm{~W}$ & 40 & 529 & 90.1 \\
\hline 179 & $0293622 \mathrm{~W}$ & 70 & 500 & 153.7 \\
\hline 180 & $0293652 \mathrm{~W}$ & 75 & 500 & 141.7 \\
\hline 181 & $0293700 \mathrm{~W}$ & 66 & 476 & 189.6 \\
\hline 182 & $0293792 \mathrm{~W}$ & 90 & 536 & 228.1 \\
\hline 183 & $0294052 \mathrm{~W}$ & 53 & 428 & 284.5 \\
\hline 184 & $0294233 \mathrm{~W}$ & 85 & 471 & 213.6 \\
\hline 185 & $0294417 \mathrm{~W}$ & 67 & 506 & 153.9 \\
\hline
\end{tabular}

then exported as a database file (dbf) to use Microsoft Excel for further computations.

In the case of the isohyetal method, the Spatial Analyst Tools (Interpolation and Reclass) extension in ArcGIS ${ }^{\mathrm{TM}} 9.3$ was used to generate and reclassify a MAP Raster (based on the design point rainfall depths at 3946 rainfall stations contained in RLMA-SAWS database) at a defined isohyetal interval of $25 \mathrm{~mm}$. The raster was based on a cell matrix approach, which represents the maximum change in design rainfall over the distance between the cell and its 8 neighbouring cells, thus representative of the maximum average design rainfall for each cell. The Conversion Tools extension was then used to convert the raster to a polygon feature class to enable the determination of the areas associated with each isohyetal interval or MAP range.

The RLMA\&SI gridded design point rainfall values were converted into an average catchment value by making use of the following steps:

- Step 1 - The averaged design rainfall representative of the average meteorological conditions in each catchment was estimated by using the Thiessen polygon method applied to all of the daily design rainfall stations (from the RLMASAWS database) within the catchment boundary. Both the MAP and average design rainfall depths (for storm durations of 1 to 7 days) were estimated.

- Step 2 - A single rainfall station, with a sufficiently long record length and which is representative of the average meteorological conditions as estimated in Step 1, was then selected from those stations used in Step 1 as the base station to estimate the RLMA\&SI gridded design point rainfall values.

- Step 3-With the single rainfall station as selected in Step 2 , the appropriate storm durations (5 min to 7 days), return periods ( 2 to 200 years) and block size (spatial resolution of 1'x1' grid points) were selected. The block size was specified in such a way that the whole extent of each catchment under consideration was covered with grid points.

- Step 4-Lastly, the gridded point values for each storm duration and return period under consideration were converted to an averaged catchment value by making use of the arithmetic mean.

\section{Critical storm duration rainfall}

The design rainfall depths for critical storm durations were estimated based on the following approaches:

- DDF relationship based on LEV1 distributions developed by $M \& P$

- DDF relationship based on the modified Hershfield equation and/or RLMA-SAWS daily design rainfall database as statistically analysed and regionalised by Smithers and Schulze (2000b)

- DDF relationship based on the RLMA\&SI approach

The critical storm duration in each case was determined by using Eq. (3), which represents $T_{C}$ in a natural, defined watercourse. All of the catchments evaluated can be classified as medium to large (only $5 \%$ of the catchments have areas $<100 \mathrm{~km}^{2}$ ) and therefore all overland flow (Eq. (2)) was regarded as main watercourse flow and included as part of the main watercourse flow path length. Eq. (3) was preferred to Eq. (4), since it is generally used and accepted in South Africa, while SANRAL (2006) also recommends the use thereof. The degree of association between these 2 equations is high, but Eq. (4) tends to underestimate the $T_{C}$-values compared to Eq. (3). Consequently, this will result in higher peak discharge estimations.

The use of Eq. (5) was discarded, since all of the catchments are rural, with no or a few artificial/man-made canals. In addition, the use of Eq. (5) is very sensitive to selecting the appropriate surface roughness parameter in terms of the Manning's $(n)$ and/or Chézy's $(k)$ coefficients. In the case of overland flow, an increase in surface roughness will result in flow retention and subsequently higher potential infiltration rates. An increased roughness in channels will result in lower velocities, deeper flow depths and higher associated flood levels, and a possible reduction in erosion or sediment transport (McCuen, 2005).

Thus, the DDF relationships were then categorised according to $3 T_{C}$-ranges; $T_{C} \leq 6 \mathrm{~h}, 6<T_{C} \leq 24 \mathrm{~h}$ and $24<T_{C} \leq 168 \mathrm{~h}$.

\section{Areal reduction factors}

The ARF in each catchment under consideration, in other words the conversion of design point rainfall depths or intensities to average areal design rainfall depths or intensities, was established by using Eq. (12). The validity of this equation was assessed by plotting $T_{C}$ within each catchment under consideration against the catchment area, after which it was superimposed on both an ARF curve based on Eq. (12) and the ARF diagram as published in the UK FSR (NERC, 1975).

\section{Days of thunder per year}

The average number of days per year on which thunder was heard $(R)$ is an input parameter required by the modified Hershfield equation (Eq. 11). This parameter is associated with the type of rainfall, e.g. convective rainfall is normally 


\begin{tabular}{|c|c|c|c|c|c|c|c|}
\hline & Avera & LMA-S & lesign ra & $\begin{array}{l}\text { e } 5 \\
\text { depths }\end{array}$ & primar & area ( & \\
\hline Duration & & & eturn peri & ars) / De & infall de & & \\
\hline & 2 & 5 & 10 & 20 & 50 & 100 & 200 \\
\hline Arithmetic & in meth & & & & & & \\
\hline MAP (mn & & & & & & 439.0 & \\
\hline 2-year me & f annu & $y$ maxin & fall $(M)$ & & & 45.0 & \\
\hline Days of th & er per & & & & & 57.1 & \\
\hline 1 & 45.0 & 61.4 & 72.9 & 84.4 & 99.8 & 111.9 & 124.5 \\
\hline 2 & 55.6 & 76.3 & 90.8 & 105.4 & 125.2 & 140.8 & 157.1 \\
\hline 3 & 61.5 & 84.7 & 101.1 & 117.7 & 140.5 & 158.7 & 177.8 \\
\hline 7 & 75.8 & 105.7 & 127.5 & 150.0 & 181.9 & 208.0 & 236.1 \\
\hline Thiessen $p$ & jon met & & & & & & \\
\hline MAP (mn & & & & & & 424.0 & \\
\hline 2-year Me & $f$ annu & y maxir & afall $(M)$ & & & 44.7 & \\
\hline Days of th & er per & & & & & 56.7 & \\
\hline 1 & 44.7 & 61.2 & 72.6 & 84.1 & 99.6 & 111.7 & 124.2 \\
\hline 2 & 55.1 & 75.7 & 90.1 & 104.7 & 124.6 & 140.2 & 156.5 \\
\hline 3 & 60.7 & 83.8 & 100.2 & 116.8 & 139.7 & 158.0 & 177.2 \\
\hline 7 & 74.6 & 104.5 & 126.3 & 148.9 & 181.0 & 207.3 & 235.8 \\
\hline Isohyetal n & & & & & & & \\
\hline MAP (mn & & & & & & 413.0 & \\
\hline 2-year me & f annu & $y$ maxin & fall $(M)$ & & & 45.0 & \\
\hline Days of th & er per & & & & & 56.4 & \\
\hline 1 & 45.0 & 61.5 & 73.0 & 84.4 & 99.8 & 111.8 & 124.1 \\
\hline 2 & 55.9 & 76.9 & 91.5 & 106.2 & 126.3 & 142.1 & 158.5 \\
\hline 3 & 61.4 & 84.9 & 101.5 & 118.4 & 141.8 & 160.4 & 180.1 \\
\hline 7 & 74.5 & 104.6 & 126.7 & 149.7 & 182.5 & 209.5 & 238.8 \\
\hline
\end{tabular}

\begin{tabular}{|l|c|c|c|c|}
\hline \multicolumn{5}{|c|}{ MAP of the 12 catchments within the primary study area (C5) } \\
\cline { 2 - 4 } $\begin{array}{l}\text { Catchment } \\
\text { description }\end{array}$ & Arithmetic mean & Thiessen polygon & Isohyetal method & $\begin{array}{c}\text { Number of rainfall } \\
\text { stations }\left(\boldsymbol{N}_{\boldsymbol{i}}\right)\end{array}$ \\
\hline Study area & 439 & 424 & 413 & 185 \\
\hline C5H003 & 553 & 549 & 543 & 8 \\
\hline C5H012 & 448 & 444 & 434 & 11 \\
\hline C5H015 & 530 & 518 & 505 & 47 \\
\hline C5H016 & 440 & 429 & 417 & 183 \\
\hline C5H018 & 479 & 461 & 448 & 93 \\
\hline C5H022 & 686 & 660 & 563 & 3 \\
\hline C5H054 & 542 & 523 & 502 & 13 \\
\hline C5R001 & 492 & 488 & 473 & 7 \\
\hline C5R002 & 421 & 420 & 406 & 61 \\
\hline C5R003 & 553 & 549 & 521 & 8 \\
\hline C5R004 & 530 & 518 & 505 & 47 \\
\hline C5R005 & 642 & 660 & 563 & 3 \\
\hline
\end{tabular}

associated with a higher degree of thunder activities than, for instance, frontal rain. The $R$-values used in this study were based on the climate data as published in the SAWB publication WB 42 (SAWB, 1992) and the generalised isohyetal map contained in Alexander (2001). There are 280 rainfall stations with associated $R$-values in WB 42 , thus representing only $\pm 7 \%$ of the total number of rainfall stations available in the RLMA-SAWS database as developed by Smithers and Schulze (2000b).

The above-mentioned isohyetal map and data contained in WB 42 were used to establish $R$-values for the remaining 3666 rainfall stations by means of linear interpolation. The 280 stations used were also allocated to the 4 synthetic 24-h distribution regions of design rainfall intensity as occurring in southern Africa and commonly used in the Soil Conservation Services (SCS) method (Schulze et al., 1992). Typically, the Type 1 and 2 storm distributions apply to coastal areas with winter rainfall or rainfall throughout the year (frontal), while the Type 3 and 4 storm distributions apply to inland areas characterised by high design rainfall intensities and convection activity. This was done by superimposing the 'Area distribution of storm types in South Africa' map over the 'SAWS rainfall station reference grid' map (SANRAL, 2006).

The $R$ and the 2-year mean of the annual daily maxima rainfall $(M)$ values were then plotted against one another to establish whether any direct relationship exists which can be 
used to express the $R$-values in terms of the $M$-values. The anticipated results will thus exclude the degree of uncertainty associated with the selection of default $R$-values based on location only.

\begin{tabular}{|c|c|c|c|}
\hline \multicolumn{4}{|c|}{$\begin{array}{c}\text { Table } 7 \\
\text { MAP of the } 29 \text { secondary study areas (RSA) }\end{array}$} \\
\hline \multirow{2}{*}{$\begin{array}{l}\text { Catchment } \\
\text { description }\end{array}$} & \multicolumn{2}{|c|}{$\operatorname{MAP}(\mathrm{mm})$} & \multirow{2}{*}{$\begin{array}{c}\text { Number of } \\
\text { rainfall } \\
\text { stations }\left(N_{i}\right)\end{array}$} \\
\hline & $\begin{array}{c}\text { Arithmetic } \\
\text { mean }\end{array}$ & $\begin{array}{l}\text { Thiessen } \\
\text { polygon }\end{array}$ & \\
\hline A2H012 & 726 & 692 & 40 \\
\hline A4H002 & 629 & 637 & 7 \\
\hline A6H006 & 634 & 630 & 3 \\
\hline B4H003 & 709 & 702 & 10 \\
\hline B7H004 & 957 & 1086 & 2 \\
\hline $\mathrm{C} 3 \mathrm{H} 003$ & 527 & 525 & 39 \\
\hline C4H001 & 572 & 568 & 31 \\
\hline $\mathrm{C} 4 \mathrm{H} 002$ & 547 & 541 & 61 \\
\hline C8H001 & 687 & 680 & 65 \\
\hline $\mathrm{C} 8 \mathrm{H} 003$ & 647 & 647 & 1 \\
\hline D1H001 & 452 & 460 & 27 \\
\hline D1H005 & 703 & 656 & 8 \\
\hline D2H001 & 698 & 742 & 65 \\
\hline E2H003 & 292 & 234 & 25 \\
\hline G1H008 & 712 & 554 & 2 \\
\hline H7H004 & 333 & 333 & 1 \\
\hline Q1H001 & 349 & 343 & 35 \\
\hline Q7H003 & 369 & 359 & 78 \\
\hline Q9H004 & 732 & 631 & 4 \\
\hline Q9H008 & 713 & 679 & 10 \\
\hline Q9H010 & 418 & 398 & 111 \\
\hline Q9H012 & 374 & 366 & 89 \\
\hline R1H001 & 926 & 791 & 2 \\
\hline T3H004 & 779 & 766 & 6 \\
\hline $\mathrm{V} 2 \mathrm{H} 002$ & 1065 & 1012 & 4 \\
\hline V6H002 & 912 & 856 & 29 \\
\hline W5H005 & 839 & 832 & 3 \\
\hline W5H006 & 887 & 887 & 1 \\
\hline $\mathrm{X} 2 \mathrm{H} 010$ & 1305 & 1305 & 1 \\
\hline
\end{tabular}

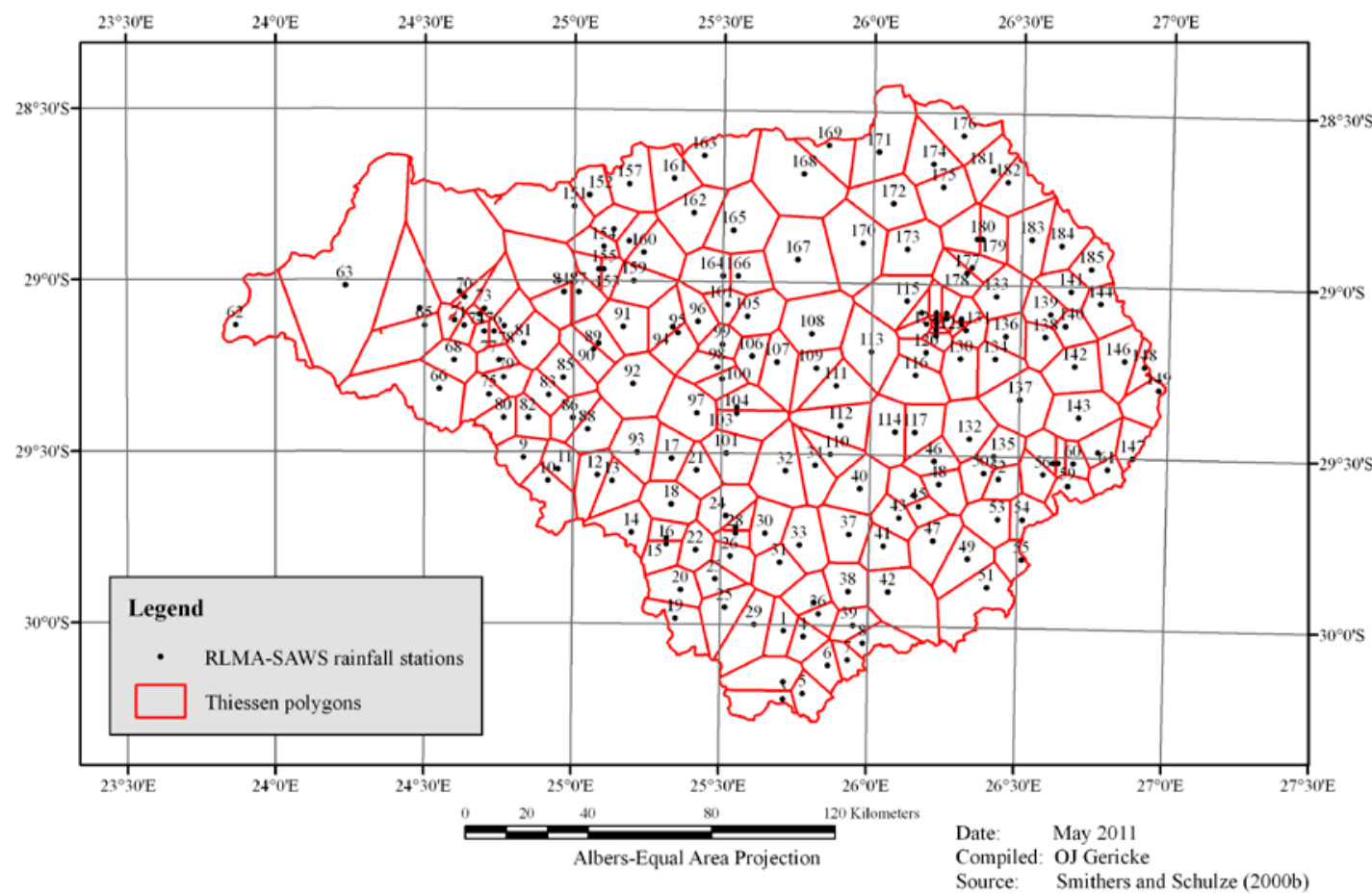

\section{Results and discussion}

\section{Averaging of rainfall depth}

The results of the averaged design rainfall depth calculations applicable to the primary and secondary study areas are listed in Tables 5, 6 and 7 respectively. Figures 3 and 4 are illustrative of the Thiessen polygon and isohyetal weighted areas and location of the daily design rainfall stations within the primary study area, while Fig. 5 serves as a visual comparison between the arithmetic mean, Thiessen polygon and isohyetal methods.

The number of rainfall stations used for averaging the rainfall varied from catchment to catchment with an overall average of 1 station per $100 \mathrm{~km}^{2}$. The arithmetic mean values exceeded both the Thiessen polygon and isohyetal values in all of the catchments, with the exception of C5R005. However, this was also the only catchment where the polygons and isohyets were based on rainfall stations within and outside the catchment boundary. The percentage differences between the arithmetic mean and Thiessen polygon methods varied between $-3 \%$ and $4 \%$, while the arithmetic mean and isohyetal method differed with between $2 \%$ and $22 \%$. Similar trends were evident between the Thiessen polygon and isohyetal methods, with differences between $1 \%$ and $17 \%$. Despite these percentage differences, the coefficient of determination $\left(r^{2}\right)$ varied between 0.90 and 0.98 , which is indicative of an overall high degree of association between these methods. This also confirmed the even areal distribution of the rainfall stations and the relatively flat topography of the $\mathrm{C} 5$ secondary drainage region (main study area). Similar results were evident in the secondary study areas.

\section{Critical storm duration rainfall}

The design rainfall depths for critical catchment storm durations, estimated using the various DDF relationships for the specific catchments evaluated in the primary and secondary study areas, are listed in Tables 8 to 10 .
Figure 3

Thiessen polygons in the primary study area (C5) 

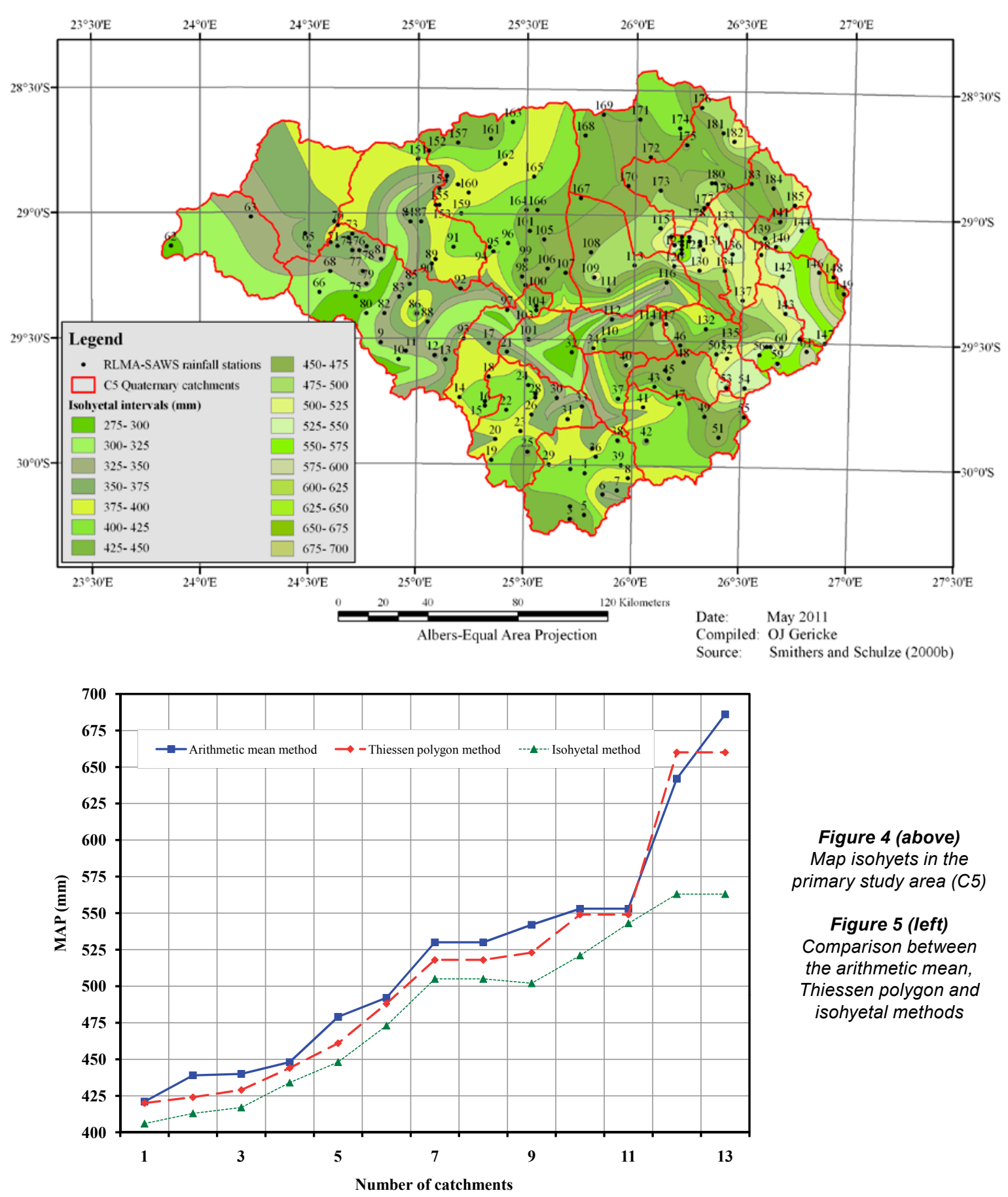

Figure 4 (above)

Map isohyets in the

primary study area (C5)

Figure 5 (left)

Comparison between

the arithmetic mean,

Thiessen polygon and

isohyetal methods

The results in Table $8\left(T_{C} \leq 6 \mathrm{~h}\right)$ indicated that the design rainfall estimated according to the $\mathrm{M} \& \mathrm{P} / \mathrm{LEV} 1$ relationship overestimated the design rainfall depths for all the return periods, when compared to the estimates using the modified Hershfield equation and the RMLA\&SI approach, except at the 10- to 50-year return periods in Catchments A6H006 and C5H022. In Catchment H7H004, M\&P/LEV1 underestimated all of the design rainfall depths when compared to the 2 other approaches. The coefficient of determination $\left(r^{2}\right)$ was a constant value of 0.76 for each return period when the M\&P/LEV1 and Hershfield methodologies within the critical storm duration range under consideration were compared. The degree of association between the M\&P/LEV1 and RMLA\&SI relationships decreased from 0.77 (10-year) to 0.71 (200-year). Compared to the RLMA\&SI approach, the modified Hershfield equation generally slightly underestimated the design rainfall depths for the 10- and 20-year return periods in catchment G1H008, while all of the return periods in Catchment H7H004 were underestimated. The rainfall depths were slightly overestimated in the remaining catchments. The degree of association between these 2 methods was high, since the coefficient of determination varied between 0.93 at the 10 -year return period and decreased to 0.87 at the 200 -year return period. Figure 6 is illustrative of the average design rainfall depths based on the 3 DDF relationships within the critical storm duration range; $T_{C} \leq 6 \mathrm{~h}$ for all of the catchments listed in Table 8 .

The results in Table $9\left(6<T_{C} \leq 24 \mathrm{~h}\right)$ showed that all the DDF relationships under consideration demonstrated, on average, similar trends, as in the case of the critical storm duration range, $T_{C} \leq 6 \mathrm{~h}$, but the overall degree of 


\begin{tabular}{|c|c|c|c|c|c|c|c|}
\hline & & esign rainfall & $\begin{array}{l}\text { Table } \\
\text { lepth }\end{array}$ & $r T_{c} \leq$ & lours & & \\
\hline Catc & 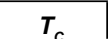 & DDF & & Design $r$ & nfall de & ths $(\mathrm{mm})$ & \\
\hline desc & (hours) & relationship & $\mathbf{P}_{10}$ & $\mathbf{P}_{20}$ & $\mathbf{P}_{50}$ & $\mathbf{P}_{100}$ & $\mathbf{P}_{200}$ \\
\hline & & M\&P/LEV1 & 71.5 & 88.2 & 114.7 & 141.2 & 158.8 \\
\hline A6H006 & 4.4 & Hershfield & 77.1 & 95.3 & 119.3 & 137.4 & 155.6 \\
\hline & & \begin{tabular}{|l|} 
RLMA\&SI \\
\end{tabular} & 72 & 83.8 & 100.3 & 113.5 & 127.5 \\
\hline & & M\&P/LEV1 & 112.2 & 138.5 & 180.1 & 221.6 & 249.3 \\
\hline В7H004 & 3.7 & Hershfield & 110.8 & 136.8 & 171.3 & 197.4 & 223.5 \\
\hline & & RLMA\&SI & 94.6 & 112.4 & 148.8 & 160.8 & 185.3 \\
\hline & & M\&P/LEV1 & 61 & 75.3 & 97.8 & 120.4 & 135.4 \\
\hline $\mathrm{C} 5 \mathrm{H} 022$ & 1.6 & Hershfield & 63.3 & 78.3 & 98.0 & 112.9 & 127.8 \\
\hline & & RLMA\&SI & 49.9 & 57.8 & 68.8 & 77.6 & 86.9 \\
\hline & & M\&P/LEV1 & 49.2 & 60.7 & 78.9 & 97.1 & 109.3 \\
\hline G1H008 & 4 & Hershfield & 36.7 & 45.4 & 56.8 & 65.5 & 74.1 \\
\hline & & RLMA\&SI & 41.2 & 46.2 & 52.6 & 57.4 & 62.1 \\
\hline & & M\&P/LEV1 & 27.6 & 34.1 & 44.3 & 54.6 & 61.4 \\
\hline H7H004 & 2.3 & Hershfield & 42.1 & 52.0 & 65.1 & 75.0 & 84.9 \\
\hline & & \begin{tabular}{|l|} 
RLMA\&SI \\
\end{tabular} & 49.3 & 59.6 & 74.7 & 87.5 & 101.6 \\
\hline & & M\&P/LEV1 & 98.3 & 121.3 & 157.7 & 194.1 & 218.4 \\
\hline W5H006 & 5 & Hershfield & 85.3 & 105.4 & 132.0 & 152.1 & 172.2 \\
\hline & & RLMA\&SI & 82.4 & 98.0 & 120.8 & 140.1 & 161.4 \\
\hline & & M\&P/LEV1 & 130.1 & 160.7 & 208.9 & 257.0 & 289.2 \\
\hline $\mathrm{X} 2 \mathrm{H} 010$ & 3.3 & Hershfield & 86.9 & 107.3 & 134.4 & 154.8 & 175.3 \\
\hline & & RLMA\&SI & 82.3 & 97.8 & 120.5 & 139.8 & 161.1 \\
\hline
\end{tabular}

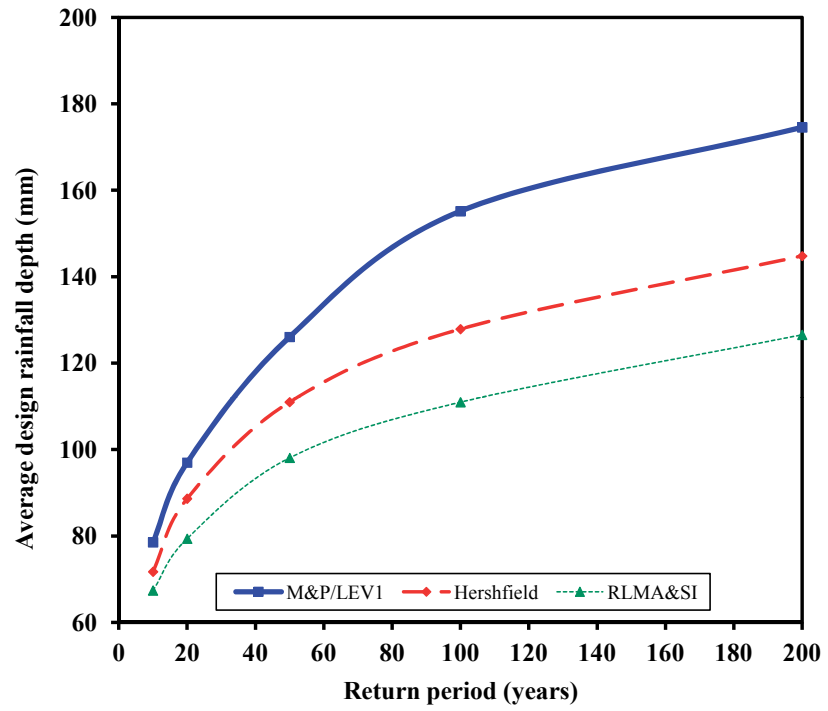

Figure 6

Average design rainfall depth: $T_{C} \leq 6 h$

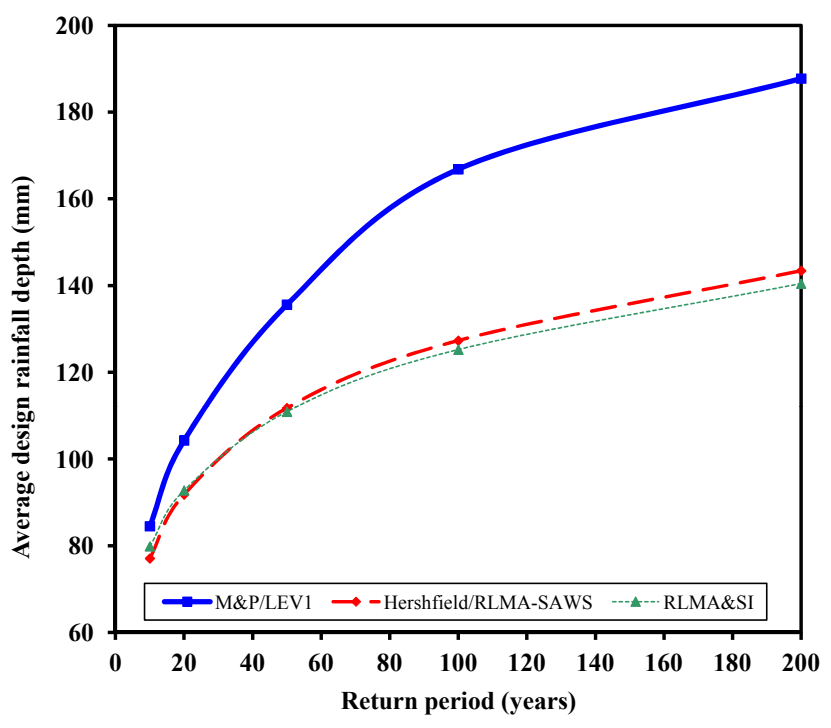

Figure 7

Average design rainfall depth: $6<T_{C} \leq 24 \mathrm{~h}$

latter case, although the $r^{2}$-values increased with an increase in return period. The Hershfield/RLMA-SAWS relationship overestimated the design rainfall depths for the full range of return periods under consideration, in comparison to the RLMA\&SI relationship in $39 \%$ of the catchments. The design rainfall depths were also underestimated in $39 \%$ of the catchments, while the results in the remaining $22 \%$ of the catchments (A4H002, C5H003, C8H003 and Q1H001) were characterised by an almost perfect fit. The degree of association was acceptable; the $r^{2}$-values varied from 0.80 at the 10 -year return period and decreased to 0.69 at the 200 -year return period. Figure 7 is illustrative of the average design rainfall depths based on the 3 DDF relationships within the critical 


\begin{tabular}{|c|c|c|c|c|c|c|c|}
\hline \multicolumn{8}{|c|}{$\begin{array}{c}\text { Table } 9 \\
\text { Design rainfall depths for } 6<T_{c} \leq \mathbf{2 4} \text { hours }\end{array}$} \\
\hline \multirow{2}{*}{$\begin{array}{l}\text { Catchment } \\
\text { description }\end{array}$} & \multirow{2}{*}{$\begin{array}{c}T_{c} \\
\text { (hours) }\end{array}$} & \multirow{2}{*}{\begin{tabular}{|l} 
DDF \\
relationship
\end{tabular}} & \multicolumn{5}{|c|}{ Design rainfall depths $(\mathrm{mm})$} \\
\hline & & & $P_{10}$ & $\mathbf{P}_{20}$ & $\mathbf{P}_{50}$ & $\mathbf{P}_{100}$ & $\mathbf{P}_{200}$ \\
\hline \multirow{3}{*}{ A2H012 } & \multirow{3}{*}{18} & M\&P/LEV1 & 94.6 & 116.8 & 151.8 & 186.3 & 210.2 \\
\hline & & Hershfield/RLMA-SAWS & 81.3 & 97.6 & 120.6 & 138.2 & 158.9 \\
\hline & & RLMA\&SI & 92.9 & 109.4 & 133.4 & 153.2 & 175.0 \\
\hline \multirow{3}{*}{ A4H002 } & \multirow{3}{*}{18.1} & M\&P/LEV1 & 88.2 & 108.8 & 141.5 & 174.2 & 195.9 \\
\hline & & Hershfield/RLMA-SAWS & 92.6 & 109.8 & 133.3 & 151.8 & 171.0 \\
\hline & & RLMA\&SI & 94.3 & 109.7 & 131.2 & 148.6 & 166.9 \\
\hline \multirow{3}{*}{ B4H003 } & \multirow{3}{*}{19.6} & M\&P/LEV1 & 96.8 & 119.5 & 155.4 & 191.2 & 215.1 \\
\hline & & Hershfield/RLMA-SAWS & 75.2 & 88.2 & 105.6 & 119.3 & 133.4 \\
\hline & & RLMA\&SI & 85.1 & 96.6 & 115.2 & 124.1 & 136.2 \\
\hline \multirow{3}{*}{$\mathrm{C} 5 \mathrm{H} 003$} & \multirow{3}{*}{18.3} & M\&P/LEV1 & 77.9 & 96.2 & 125.1 & 153.9 & 173.2 \\
\hline & & \begin{tabular}{|l|} 
Hershfield/RLMA-SAWS \\
\end{tabular} & 78.5 & 93.0 & 112.7 & 128.0 & 143.8 \\
\hline & & RLMA\&SI & 80.3 & 92.6 & 109.1 & 121.9 & 135.1 \\
\hline \multirow{3}{*}{$\mathrm{C} 5 \mathrm{H} 008$} & \multirow{3}{*}{11.9} & M\&P/LEV1 & 59.2 & 73.1 & 95.1 & 117.0 & 131.6 \\
\hline & & Hershfield/RLMA-SAWS & 71.0 & 86.1 & 106.2 & 121.6 & 137.3 \\
\hline & & RLMA\&SI & 65.8 & 76.4 & 90.9 & 102.5 & 114.7 \\
\hline \multirow{3}{*}{$\mathrm{C} 5 \mathrm{H} 012$} & \multirow{3}{*}{20.2} & M\&P/LEV1 & 66.4 & 81.9 & 106.5 & 131.1 & 147.5 \\
\hline & & Hershfield/RLMA-SAWS & 70.5 & 82.7 & 99.1 & 111.8 & 124.8 \\
\hline & & RLMA\&SI & 76.9 & 89.1 & 106.1 & 119.6 & 133.9 \\
\hline & & M\&P/LEV1 & 74.4 & 91.8 & 119.4 & 146.9 & 165.3 \\
\hline C5H054 & 16.9 & Hershfield/RLMA-SAWS & 79.8 & 94.7 & 114.6 & 130.0 & 145.5 \\
\hline & & RLMA\&SI & 77.6 & 89.3 & 105.3 & 117.7 & 130.5 \\
\hline & & M\&P/LEV1 & 72.1 & 89.0 & 115.7 & 142.4 & 160.2 \\
\hline C5R001 & 21.3 & Hershfield/RLMA-SAWS & 73.4 & 85.8 & 102.7 & 115.9 & 129.6 \\
\hline & & RLMA\&SI & 84.6 & 98.1 & 116.7 & 131.7 & 147.4 \\
\hline & & M\&P/LEV1 & 75.2 & 92.8 & 120.6 & 148.5 & 167.0 \\
\hline C5R003 & 13.9 & \begin{tabular}{|l|} 
Hershfield/RLMA-SAWS \\
\end{tabular} & 80.5 & 96.8 & 118.8 & 135.7 & 152.9 \\
\hline & & RLMA\&SI & 80.7 & 93.5 & 111.4 & 125.6 & 138.4 \\
\hline & & M\&P/LEV1 & 90.0 & 111.1 & 144.5 & 177.8 & 200.1 \\
\hline $\mathrm{C} 8 \mathrm{H} 003$ & 19.2 & \begin{tabular}{|l|} 
Hershfield/RLMA-SAWS \\
\end{tabular} & 79.0 & 92.4 & 110.3 & 124.2 & 138.4 \\
\hline & & RLMA\&SI & 83.5 & 95.4 & 111.6 & 124.4 & 137.7 \\
\hline & & M\&P/LEV1 & 68.1 & 84.1 & 109.3 & 134.5 & 151.4 \\
\hline D1H001 & 19.9 & Hershfield/RLMA-SAWS & 68.5 & 79.7 & 94.7 & 106.2 & 117.8 \\
\hline & & RLMA\&SI & 66.9 & 76.0 & 87.8 & 96.5 & 105.3 \\
\hline & & M\&P/LEV1 & 53.5 & 66.0 & 85.8 & 105.6 & 118.8 \\
\hline Q1H001 & 18 & Hershfield/RLMA-SAWS & 55.0 & 63.7 & 75.2 & 84.2 & 93.4 \\
\hline & & RLMA\&SI & 54.7 & 63.2 & 74.7 & 83.9 & 93.1 \\
\hline & & M\&P/LEV1 & 75.7 & 93.4 & 121.5 & 149.5 & 168.2 \\
\hline Q9H004 & 6.3 & \begin{tabular}{|l|} 
Hershfield/RLMA-SAWS \\
\end{tabular} & 67.0 & 82.7 & 103.5 & 119.2 & 134.9 \\
\hline & & RLMA\&SI & 60.0 & 70.2 & 84.5 & 95.9 & 108.0 \\
\hline & & M\&P/LEV1 & 88.9 & 109.8 & 142.7 & 175.6 & 197.6 \\
\hline Q9H008 & 12.7 & \begin{tabular}{|l|} 
Hershfield/RLMA-SAWS \\
\end{tabular} & 70.8 & 85.6 & 105.5 & 120.9 & 136.6 \\
\hline & & RLMA\&SI & 63.9 & 74.8 & 89.9 & 102.1 & 114.9 \\
\hline & & M\&P/LEV1 & 91.8 & 113.3 & 147.3 & 181.3 & 204.0 \\
\hline R1H001 & 6.2 & Hershfield/RLMA-SAWS & 75.0 & 92.7 & 115.9 & 133.6 & 151.2 \\
\hline & & RLMA\&SI & 62.2 & 72.8 & 87.5 & 99.3 & 111.9 \\
\hline & & M\&P/LEV1 & 103.9 & 128.3 & 166.7 & 205.2 & 230.9 \\
\hline Т3H004 & 18.8 & Hershfield/RLMA-SAWS & 87.8 & 104.1 & 126.6 & 144.5 & 163.1 \\
\hline & & RLMA\&SI & 97.6 & 115.1 & 140.2 & 161.3 & 184.4 \\
\hline & & M\&P/LEV1 & 133.1 & 164.4 & 213.7 & 263.0 & 295.9 \\
\hline V2H002 & 18.9 & Hershfield/RLMA-SAWS & 86.5 & 102.5 & 124.7 & 142.3 & 160.7 \\
\hline & & RLMA\&SI & 98.7 & 115.1 & 138.0 & 156.7 & 176.7 \\
\hline & & M\&P/LEV1 & 110.9 & 136.9 & 178.0 & 219.1 & 246.5 \\
\hline W5H005 & 17.8 & Hershfield/RLMA-SAWS & 95.0 & 114.4 & 141.7 & 164.1 & 187.9 \\
\hline & & RLMA\&SI & 111.3 & 132.3 & 162.9 & 189.0 & 217.7 \\
\hline
\end{tabular}




\begin{tabular}{|c|c|c|c|c|c|c|c|}
\hline \multicolumn{8}{|c|}{$\begin{array}{c}\text { Table } 10 \\
\text { Design rainfall depths for } 24<T_{c} \leq 168 \text { hours }\end{array}$} \\
\hline \multirow{2}{*}{$\begin{array}{l}\text { Catchment } \\
\text { description }\end{array}$} & \multirow{2}{*}{$\begin{array}{c}T_{c} \\
\text { (hours) }\end{array}$} & \multirow{2}{*}{$\begin{array}{l}\text { DDF } \\
\text { relationship }\end{array}$} & \multicolumn{5}{|c|}{ Design rainfall depth $(\mathrm{mm})$} \\
\hline & & & $\mathbf{P}_{10}$ & $\mathbf{P}_{20}$ & $\mathbf{P}_{50}$ & $\mathbf{P}_{100}$ & $\mathbf{P}_{200}$ \\
\hline \multirow{3}{*}{$\mathrm{C} 3 \mathrm{H} 003$} & \multirow{3}{*}{78} & M\&P/LEV1 & 89.7 & 110.7 & 144.0 & 177.2 & 199.3 \\
\hline & & RLMA-SAWS & 113.6 & 129.6 & 150.2 & 165.5 & 180.7 \\
\hline & & RLMA\&SI & 110.0 & 127.1 & 149.8 & 167.7 & 184.9 \\
\hline \multirow{3}{*}{ C4H001 } & \multirow{3}{*}{34} & M\&P/LEV1 & 86.6 & 106.9 & 139.0 & 171.1 & 192.5 \\
\hline & & RLMA-SAWS & 93.7 & 108.5 & 128.8 & 144.9 & 161.9 \\
\hline & & RLMA\&SI & 92.1 & 106.1 & 125.1 & 139.7 & 154.7 \\
\hline \multirow{3}{*}{$\mathrm{C} 4 \mathrm{H} 002$} & \multirow{3}{*}{111} & M\&P/LEV1 & 95.9 & 118.4 & 153.9 & 189.4 & 213.1 \\
\hline & & RLMA-SAWS & 130.3 & 149.5 & 175.2 & 195.2 & 215.6 \\
\hline & & RLMA\&SI & 123.2 & 142.1 & 167.6 & 188.7 & 209.8 \\
\hline \multirow{3}{*}{ C5H015 } & \multirow{3}{*}{43} & M\&P/LEV1 & 82.6 & 102.0 & 132.6 & 163.2 & 183.6 \\
\hline & & RLMA-SAWS & 93.0 & 107.3 & 126.7 & 141.9 & 157.7 \\
\hline & & RLMA\&SI & 93.3 & 107.5 & 126.9 & 141.5 & 157.0 \\
\hline \multirow{3}{*}{ C5H016 } & \multirow{3}{*}{111.1} & M\&P/LEV1 & 79.5 & 98.1 & 127.6 & 157.0 & 176.6 \\
\hline & & \begin{tabular}{|l|} 
RLMA-SAWS \\
\end{tabular} & 110.9 & 129.7 & 156.1 & 177.4 & 200.0 \\
\hline & & RLMA\&SI & 107.0 & 123.3 & 145.3 & 162.4 & 180.0 \\
\hline \multirow{3}{*}{ C5H018 } & \multirow{3}{*}{99.6} & M\&P/LEV1 & 83.0 & 102.5 & 133.2 & 163.9 & 184.4 \\
\hline & & \begin{tabular}{|l|} 
RLMA-SAWS \\
\end{tabular} & 111.5 & 129.3 & 153.5 & 172.7 & 192.7 \\
\hline & & RLMA\&SI & 115.1 & 132.7 & 156.1 & 174.2 & 192.9 \\
\hline \multirow{3}{*}{ C5R002 } & \multirow{3}{*}{50.5} & M\&P/LEV1 & 71.1 & 87.7 & 114.0 & 140.4 & 157.9 \\
\hline & & \begin{tabular}{|l} 
RLMA-SAWS \\
\end{tabular} & 87.5 & 101.5 & 120.4 & 135.3 & 150.7 \\
\hline & & RLMA\&SI & 84.5 & 98.0 & 116.6 & 131.6 & 147.3 \\
\hline \multirow{3}{*}{ C5R004 } & & M\&P/LEV1 & 83.7 & 103.4 & 134.4 & 165.4 & 186.0 \\
\hline & 47.9 & \begin{tabular}{|l|} 
RLMA-SAWS \\
\end{tabular} & 97.0 & 111.9 & 132.0 & 147.8 & 164.2 \\
\hline & & RLMA\&SI & 90.2 & 103.9 & 122.4 & 136.8 & 151.7 \\
\hline & & M\&P/LEV1 & 117.7 & 145.3 & 188.9 & 232.4 & 261.5 \\
\hline C8H001 & 122 & RLMA-SAWS & 126.6 & 141.0 & 159 & 172.1 & 184.7 \\
\hline & & RLMA\&SI & 131.8 & 152.5 & 179.3 & 201.3 & 224.5 \\
\hline & & M\&P/LEV1 & 124.8 & 154.1 & 200.3 & 246.5 & 277.3 \\
\hline D2H001 & 106 & \begin{tabular}{|l|} 
RLMA-SAWS \\
\end{tabular} & 111.0 & 127.2 & 149.2 & 166.2 & 183.6 \\
\hline & & RLMA\&SI & 117.7 & 136.7 & 162.2 & 183.4 & 205.6 \\
\hline & & M\&P/LEV1 & 104.8 & 129.4 & 168.3 & 207.1 & 233.0 \\
\hline D1H005 & 60 & \begin{tabular}{|l} 
RLMA-SAWS \\
\end{tabular} & 91.3 & 106.0 & 126.7 & 143.6 & 161.7 \\
\hline & & RLMA\&SI & 101.4 & 118.8 & 142.2 & 161.4 & 182.4 \\
\hline & & M\&P/LEV1 & 47.0 & 58.1 & 75.5 & 92.9 & 104.5 \\
\hline E2H003 & 59 & RLMA-SAWS & 71.0 & 82.0 & 96.5 & 107.3 & 118.3 \\
\hline & & RLMA\&SI & 54.9 & 63.1 & 74.3 & 82.6 & 91.5 \\
\hline & & M\&P/LEV1 & 64.1 & 79.1 & 102.9 & 126.6 & 142.4 \\
\hline Q7H003 & 59 & \begin{tabular}{|l|} 
RLMA-SAWS \\
\end{tabular} & 70.8 & 81.8 & 96.5 & 107.8 & 119.2 \\
\hline & & RLMA\&SI & 82.1 & 95.1 & 112.5 & 126.0 & 139.9 \\
\hline & & M\&P/LEV1 & 74.6 & 92.1 & 119.7 & 147.4 & 165.8 \\
\hline Q9H010 & 108 & \begin{tabular}{|l|} 
RLMA-SAWS \\
\end{tabular} & 82.6 & 95.5 & 112.6 & 125.8 & 139.1 \\
\hline & & RLMA\&SI & 94.0 & 108.8 & 128.7 & 144.2 & 160.1 \\
\hline & & M\&P/LEV1 & 68.0 & 83.9 & 109.1 & 134.2 & 151.0 \\
\hline Q9H012 & 85 & RLMA-SAWS & 77.9 & 90.1 & 106.3 & 118.8 & 131.4 \\
\hline & & RLMA\&SI & 89.1 & 103.2 & 122.1 & 136.8 & 151.9 \\
\hline & & M\&P/LEV1 & 128.7 & 158.9 & 206.5 & 254.2 & 286.0 \\
\hline V6H002 & 48 & RLMA-SAWS & 125.6 & 142.8 & 165.3 & 182.4 & 199.5 \\
\hline & & RLMA\&SI & 129.2 & 148.1 & 173.5 & 193.1 & 213.4 \\
\hline
\end{tabular}

storm duration range, $6<T_{C} \leq 24 \mathrm{~h}$ for all of the catchments listed in Table 9.

The results in Table $10\left(24<T_{C} \leq 168 \mathrm{~h}\right)$ indicated that the $\mathrm{M} \& \mathrm{P} / \mathrm{LEV} 1$ relationship overestimated the design rainfall depths for the 50-, 100- and 200-year return periods up to a critical storm duration of $50 \mathrm{~h}$, compared to the linear interpolated RLMA-SAWS $n$-day design point rainfall depths and the RLMA\&SI approach. All of the design rainfall depths with critical storm durations of or exceeding $100 \mathrm{~h}$ were underestimated, except in Catchments C8H001, D2H001 and Q9H012. In Catchment D2H001 all of the design rainfall depths were overestimated, while only the 50-, 100- and 200-year return periods were overestimated in the other 2 catchments.

The degree of association between these methods was low, since the coefficient of determination varied between 0.60 (10-year) and decreased to 0.49 (200-year), in the case of the 


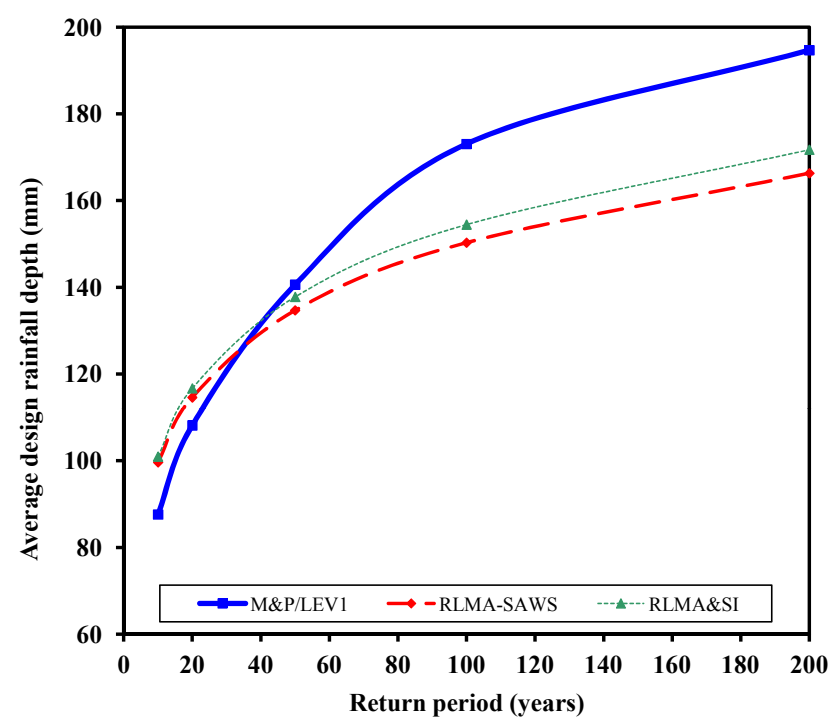

Figure 8

Average design rainfall depth: $24<T_{C} \leq 168 \mathrm{~h}$

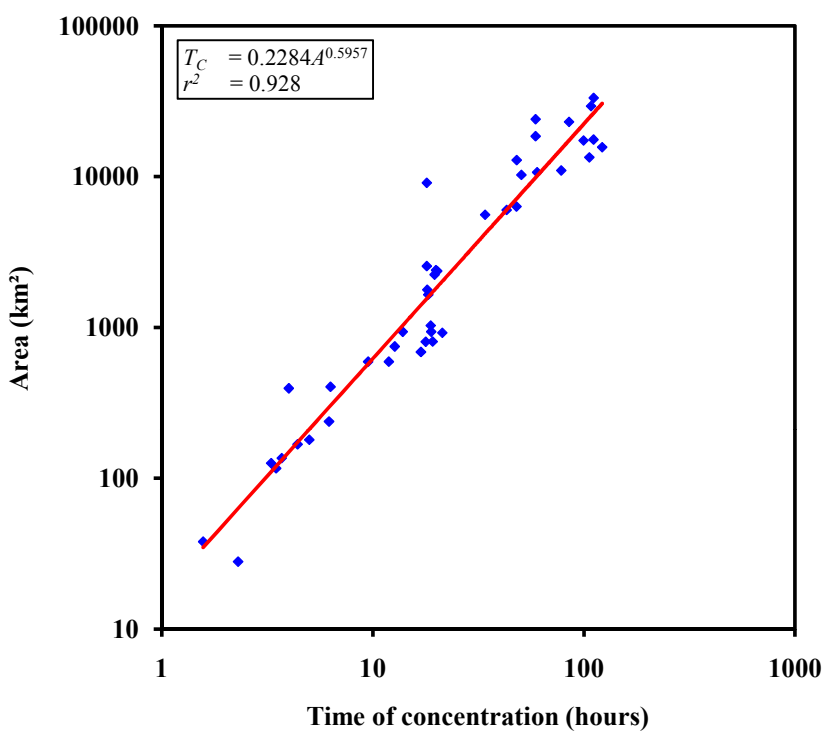

Figure 9

ARF: Area versus time of concentration power-law curve

M\&P/LEV1 and RLMA-SAWS comparison, while in the case of the M\&P/LEV1 and RMLA\&SI comparison the coefficient of determination varied between 0.75 (10-year) and increased to 0.77 at the 200 -year return period. The comparison between the RLMA\&SI and the linear-interpolated RLMA-SAWS $n$-day design point rainfall depths were characterised by a high degree of association; the coefficient of determination varied between 0.85 at the 10 -year return period and decreased to 0.72 at the 200 -year return period. Figure 8 is illustrative of the average design rainfall depths based on the 3 DDF relationships within the critical storm duration range, $24<T_{C} \leq 168 \mathrm{~h}$ for all of the catchments listed in Table 10.

In the methodology it was highlighted that the RLMA\&SI gridded design point rainfall values were converted into average catchment values by using a 4 -step process. In order to establish the applicability thereof, the RLMA\&SI design rainfall depth results in 4 of the 29 secondary study areas were compared to the results obtained by Parak and Pegram (2006).

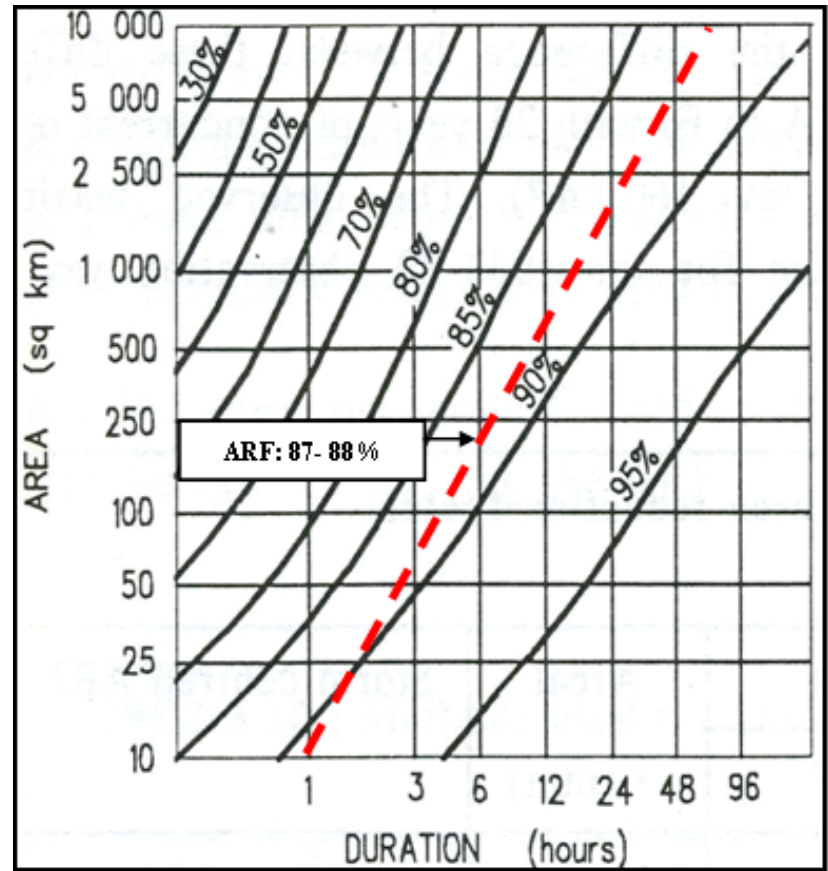

Figure 10

ARF diagram derived from fixed storm data (NERC, 1975; as cited in Alexander, 1990)

The catchments used for these comparisons were: Q7H003, Q9H010, Q9H012 and V6H002. In these catchments, the design rainfall estimates by Parak and Pegram (2006) differed with between $25 \%$ (10-year) and 34\% (200-year) from this study; compared to the M\&P/LEV1 and RLMA-SAWS estimates, the differences varied between $26 \%$ and $56 \%$. These differences might be ascribed to the fact that Parak and Pegram (2006) followed a different approach to averaging the design rainfall depths. They chose a number of locations (depending on the size of the catchment) along the main watercourse within the catchment, for which design rainfall depth estimates based on the RLMA\&SI approach were then obtained. The average depth for each catchment was determined, and thereafter the intensity, duration and frequency relationships were derived by fitting a simple power-law function of storm duration $\left(T_{C}\right)$ to the average design rainfall depths. At the 10 - to 200 -year return periods, their average rainfall depths and intensities were expressed in the form of Eqs. (13) and (14):

$$
\begin{aligned}
P & =a T_{C}{ }^{b} \\
I & =a T_{C}{ }^{-c}
\end{aligned}
$$

where:

$$
\begin{aligned}
& a, b, c=\text { fitted power-law parameters, with } \mathrm{c}=\mathrm{b}-1 \\
& I \quad=\text { average rainfall intensity }\left(\mathrm{mm} \cdot \mathrm{h}^{-1}\right) \\
& P \quad=\text { average rainfall depth }(\mathrm{mm}) \\
& T_{C}=\text { time of concentration }(\mathrm{h})
\end{aligned}
$$

\section{Areal reduction factors}

The $T_{C}$ values were plotted against the associated catchment areas on a double log graph and a straight line fit represented by a power function was fitted through the data points. Eq. (12) is represented by a power function equal to the 1:1 trend line; 


\begin{tabular}{|c|c|c|c|c|}
\hline \multicolumn{5}{|c|}{$\begin{array}{c}\text { Table } 11 \\
\text { Comparison of ARF results: Eqs. (12) and (16) }\end{array}$} \\
\hline \multirow{2}{*}{$\begin{array}{l}\text { Catchment } \\
\text { description }\end{array}$} & \multirow{2}{*}{$\begin{array}{c}\text { Area } \\
\left(\mathbf{k m}^{2}\right)\end{array}$} & \multirow{2}{*}{$\begin{array}{c}T_{c} \\
\text { (hours) }\end{array}$} & \multicolumn{2}{|c|}{ ARF (\%) } \\
\hline & & & Eq. (12) & Eq. (16) \\
\hline A2H012 & 2551 & 18.0 & 80.6 & 82.2 \\
\hline A4H002 & 1777 & 18.1 & 83.1 & 83.5 \\
\hline A6H006 & 168 & 4.4 & 91.1 & 91.5 \\
\hline B4H003 & 2240 & 19.6 & 81.9 & 82.7 \\
\hline B7H004 & 136 & 3.7 & 91.6 & 92.2 \\
\hline $\mathrm{C} 3 \mathrm{H} 003$ & 10990 & 78.0 & 78.1 & 76.5 \\
\hline C4H001 & 5590 & 34.0 & 78.4 & 79.2 \\
\hline $\mathrm{C} 4 \mathrm{H} 002$ & 17599 & 111 & 76.6 & 74.5 \\
\hline $\mathrm{C} 5 \mathrm{H} 003$ & 1650 & 18.3 & 83.6 & 83.8 \\
\hline C5H008 & 593 & 11.9 & 88.1 & 87.4 \\
\hline $\mathrm{C} 5 \mathrm{H} 012$ & 2366.3 & 20.2 & 81.7 & 82.5 \\
\hline C5H015 & 6009 & 43.0 & 79.2 & 78.9 \\
\hline C5H016 & 33277.2 & 111.1 & 71.5 & 71.6 \\
\hline C5H018 & 17360.3 & 99.6 & 76.1 & 74.5 \\
\hline $\mathrm{C} 5 \mathrm{H} 022$ & 38 & 1.6 & 95.1 & 96.1 \\
\hline C5H054 & 687.8 & 16.9 & 88.8 & 86.9 \\
\hline C5R001 & 921.5 & 21.3 & 88.2 & 85.9 \\
\hline C5R002 & 10259.9 & 50.5 & 76.1 & 76.7 \\
\hline C5R003 & 936.7 & 13.9 & 86.0 & 85.8 \\
\hline C5R004 & 6330.9 & 47.9 & 79.4 & 78.7 \\
\hline C5R005 & 116.4 & 3.5 & 92.2 & 92.7 \\
\hline $\mathrm{C} 8 \mathrm{H} 001$ & 15673 & 122.0 & 78.1 & 75.0 \\
\hline $\mathrm{C} 8 \mathrm{H} 003$ & 806 & 19.2 & 88.5 & 86.3 \\
\hline D1H001 & 2397 & 19.9 & 81.5 & 82.4 \\
\hline D1H005 & 10680 & 60.0 & 76.8 & 76.6 \\
\hline D2H001 & 13421 & 106.0 & 78.4 & 75.6 \\
\hline E2H003 & 24044 & 59.0 & 70.1 & 73.1 \\
\hline G1H008 & 395 & 4.0 & 85.4 & 88.8 \\
\hline H3H001 & 593 & 9.5 & 87.0 & 87.4 \\
\hline H7H004 & 28 & 2.3 & 98.3 & 97.0 \\
\hline Q1H001 & 9091 & 18.0 & 70.7 & 77.2 \\
\hline Q7H003 & 18534 & 59.0 & 72.4 & 74.2 \\
\hline Q9H004 & 404 & 6.3 & 87.5 & 88.7 \\
\hline Q9H008 & 748 & 12.7 & 87.0 & 86.6 \\
\hline Q9H010 & 29328 & 108.0 & 72.4 & 72.2 \\
\hline Q9H012 & 23067 & 85.0 & 72.9 & 73.3 \\
\hline R1H001 & 238 & 6.2 & 90.6 & 90.4 \\
\hline T3H004 & 1029 & 18.8 & 86.9 & 85.5 \\
\hline V2H002 & 937 & 18.9 & 87.5 & 85.8 \\
\hline V6H002 & 12862 & 48.0 & 74.1 & 75.8 \\
\hline W5H005 & 804 & 17.8 & 88.1 & 86.3 \\
\hline W5H006 & 180 & 5.0 & 91.3 & 91.3 \\
\hline X2H010 & 126 & 3.3 & 91.5 & 92.4 \\
\hline
\end{tabular}

$$
\begin{aligned}
& A \quad=17.1208 T_{C}^{1.5571} \\
& T_{C}=0.2284 A^{0.5957} \\
& A R F=\left(\begin{array}{l}
-6944.3 \ln A+115731.9)^{0.4} \\
.
\end{array}\right.
\end{aligned}
$$

where:

$$
\begin{aligned}
& A=\text { catchment area }\left(\mathrm{km}^{2}\right) \\
& A R F=\text { areal reduction factor }(\%) \\
& T_{C}=\text { time of concentration }(\mathrm{h})
\end{aligned}
$$

A summary of the applicable results is shown in Table 11, and Fig. 9 illustrates the fitted power-law relationship.

Figure 10 represents the ARF diagram published in the UK FSR (NERC, 1975) with Fig. 9, the area-duration powerlaw curve, superimposed thereon. It is clearly evident that this power-law curve yielded a constant ARF, of between $87 \%$ and $88 \%$, across the ARF diagram, for durations exceeding $3 \mathrm{~h}$. This implies that, for the catchments under consideration, the ARFs for design point rainfall depths with durations equal to $T_{C}$ in a specific catchment appear to be fairly constant between $87 \%$ and $88 \%$. Similar results were obtained by Pegram (2003), although Eq. (15b) differed slightly.

\section{Days of thunder per year}

Figures 11 and 12 served as a confirmation that there is no direct relationship between the $R$ and $M$-values of the rainfall stations under consideration, as originally anticipated.

The data points in these figures were randomly scattered around a curve to which a third-order polynomial relationship could not even be fitted satisfactorily, especially in the case of the Type 3 and/or 4 storm distributions. The degree of association between the $R$ and $M$-values of the Type 1 and/or 2 storm distributions was higher compared to that of the Type 3 and/or 4 storm distributions, emphasising the more uniform areal and temporal distribution of rainfall, and associated lower occurrence of thunder, typical of the winter and/or coastal rainfall regions.

\section{Conclusions and recommendations}

\section{Averaging of rainfall depth}

The Thiessen polygon and isohyetal methods are the preferred methods to determine average areal design rainfall depths; especially where rainfall stations have a poor areal distribution and the catchment topography is highly variable. However, the isohyetal method requires much more data manipulation in an ArcGIS ${ }^{\mathrm{TM}}$ environment with longer associated computation times. The Thiessen polygon method is therefore recommended for future use.

\section{Critical storm duration rainfall}

On average, the $\mathrm{M} \& \mathrm{P} / \mathrm{LEV} 1$ relationship estimated the largest design rainfall depths for all of the return periods and critical storm duration ranges under consideration, except for the 10and 20 -year return periods of the $24<T_{C} \leq 168 \mathrm{~h}$ range. The Hershfield/RLMA-SAWS relationship estimated the secondhighest design rainfall depths for the full range of return periods of the $T_{C} \leq 6 \mathrm{~h}$ and $6<T_{C} \leq 24 \mathrm{~h}$ ranges. On average, the lowest design rainfall depths were estimated by the RLMA\&SI relationship, except in individual cases where the critical storm 


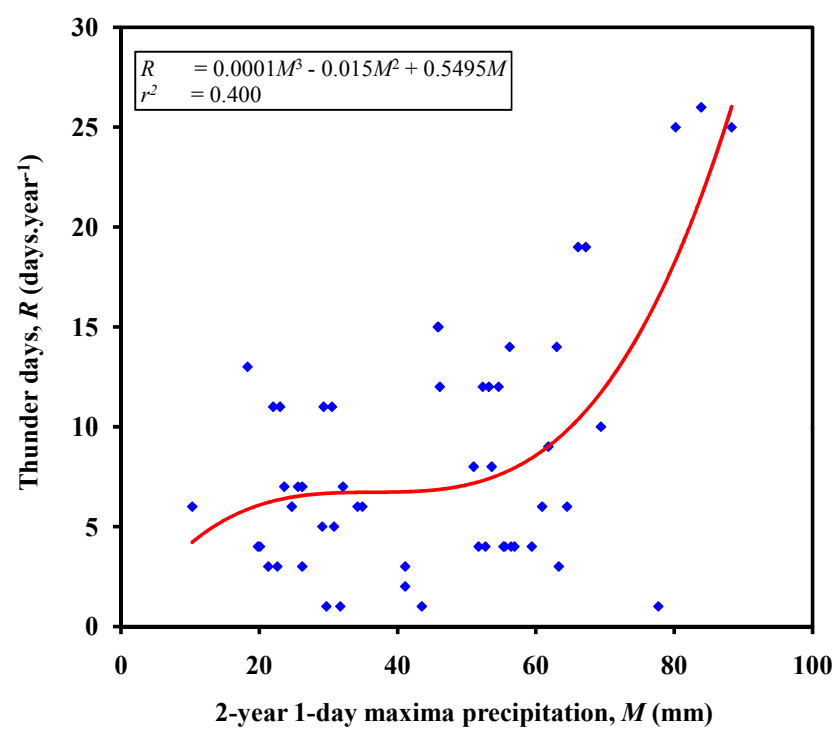

Figure 11

$R$ versus $M$-values for stations with Type 1 and/or 2 storm distributions

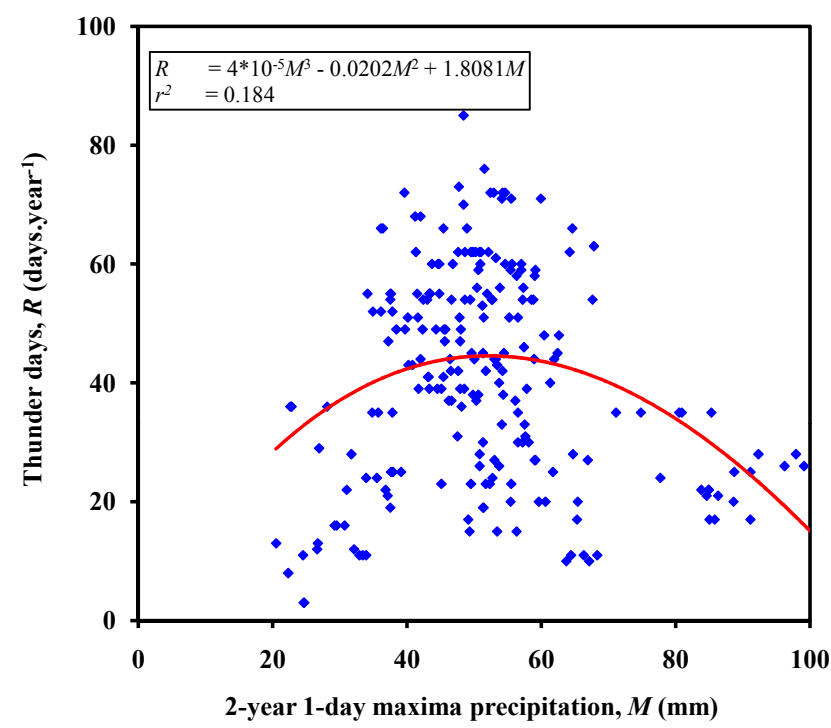

Figure 12

$R$ versus $M$-values for stations with Type 3 and/or 4 storm distributions

duration exceeded $100 \mathrm{~h}$. Here, it resulted in higher estimates compared to those of the other 2 DDF relationships. However, in $57 \%$ of the catchments with $T_{C} \leq 100 \mathrm{~h}$ at the 200 -year return period, the M\&P/LEV1 relationship provided more accurate estimates.

On average, these different DDF relationships demonstrated a high degree of association amongst each other, with $r^{2}$-values ranging from 0.71 to 0.93 for critical storm durations less than $6 \mathrm{~h}$. The critical storm durations ranging between 6 and $24 \mathrm{~h}$ were characterised by constant $r^{2}$-values of 0.53 between the M\&P/LEV1 and Hershfield/RLMASAWS relationships, while the degree of association between the Hershfield/RLMA-SAWS and RLMA\&SI relationships decreased with an increase in return period. The critical storm durations ranging between 24 and $168 \mathrm{~h}$ were characterised by an acceptable to high degree of association between all of the methods. The results also showed a tendency to decrease in association with an increase in return period.

Since all of these DDF relationships, except for the RMLA\&SI approach, are currently widely used as standard rainfall input information to the deterministic flood estimation methods used in South Africa, the question arises whether this must remain as the standard procedure. Based on the results obtained from this study, it is recommended that the M\&P/LEV1 and Hershfield DDF relationships should be seen as conservative estimates and their use should be limited to small catchments $\left(T_{C} \leq 6 \mathrm{~h}\right)$. However, the Hershfield/RLMA-SAWS relationship proved to be more reliable in medium-sized catchments $\left(6<T_{C} \leq 24 \mathrm{~h}\right)$. The RMLA\&SI approach must be used as the standard DDF relationship for all of the critical storm durations under consideration, since it utilises the scale invariance of growth curves with duration, and the Java-based software with graphical interface enables reliable and consistent design rainfall estimation in South Africa. In addition, by implementing this, the current M\&P/LEV1 relationship, which depends heavily on averaged regional conditions, and the Hershfield relationship, with the highly variable and questionable parameter - the average number of thunder days per year, can be excluded from the calculation procedures.

\section{Areal reduction factors}

Eq. (15b) can be satisfactorily used to determine $T_{C}$ associated with any catchment area under consideration in the study areas. In addition, the simplified ARF relationship expressed by Eq. (16) can be used instead of Eq. (12) to convert design point rainfall depths or intensities to average areal design rainfall depths or intensities in the identified catchments. However, the validity of both Eqs. (15b) and (16) must be further tested, improved and verified to be acceptable for general use on a national scale in South Africa.

\section{Days of thunder per year}

There was no clear relationship between the average numbers of days per year on which thunder was heard $(R)$ and the 2-year mean of the annual daily maxima rainfall $(M)$ values. The number of thunder days per year is not only influenced by the temporal distribution of storms; the climate, type of rainfall, areal distribution of rainfall, location, altitude above mean sea level and topography must be taken into consideration.

\section{References}

ADAMSON PT (1981) Southern African Storm Rainfall. Technical Report TR102. Department of Environmental Affairs and Tourism, Pretoria, RSA.

ALEXANDER WJR (1980) Depth-Area-Duration-Frequency Properties of Storm Precipitation in South Africa. Technical Report TR103. Department of Water Affairs and Forestry, Pretoria, RSA.

ALEXANDER WJR (1990) Flood Hydrology for Southern Africa. SANCOLD, Pretoria, RSA.

ALEXANDER WJR (2001) Flood Risk Reduction Measures: Incorporating Flood Hydrology for Southern Africa. Department of Civil and Biosystems Engineering, University of Pretoria, RSA

CSIR (2001) GIS Data: Classified Raster Data for National Coverage based on 31 Land Cover Types. National Land Cover Database. Environmentek, CSIR, Pretoria, RSA.

HRU (HYDROLOGICAL RESEARCH UNIT) (1972) Design Flood Determination in South Africa. Hydrological Research Unit Report $1 / 72$. University of the Witwatersrand. Johannesburg, RSA. 
KIRPICH ZP (1940) Time of concentration of small agricultural watersheds. Civ. Eng. 10 (6) 362.

MIDGLEY DC and PITMAN WV (1978) A Depth-DurationFrequency Diagram for Point Rainfall in Southern Africa. Hydrological Research Unit Report 2/78. University of the Witwatersrand, Johannesburg, RSA. 57 pp.

MIDGLEY DC, PITMAN WV and MIDDLETON BJ (1994) Surface Water Resources of South Africa. Volume 2, Drainage Region C, Vaal: Appendices. WRC Report No. 298/2.1/94. Water Research Commission, Pretoria, RSA.

McCUEN RH (2005) Hydrologic Analysis and Design ( ${ }^{\text {rd }}$ edn.). Prentice-Hall, Upper Saddle River, New York.

NERC (NATURAL ENVIRONMENT RESEARCH COUNCIL) (1975) Flood Studies Report. Natural Environment Research Council. London, UK.

PARAK M and PEGRAM GGS (2006) Rational Formula from Runhydrograph. Water $S A 32$ (2) 163-180.

PEGRAM GGS and ADAMSON PT (1988) Revised risk analysis for extreme storms and floods in Natal/KwaZulu. The Civil Engineer in South Africa (July 1988) 331-336.

PEGRAM GGS (2003) Rainfall, rational formula and regional maximum flood: Some scaling links. Keynote Paper. Aust. J. Water Resour. 7 (1) 29-39.

PETRAS V and DU PLESSIS PH (1987) Catalogue of Hydrological Catchment Parameters. Department of Water Affairs and Forestry, Flood Studies, Technical Note 6. Pretoria, RSA.

ROOSEBOOM A, BASSON MS, LOOTS CH and WIGGETT JH (1993) Manual for Road Drainage ( $4^{\text {th }}$ edn.). Department of Transport, Pretoria, RSA.

SANRAL (2006) Drainage Manual ( $5^{\text {th }}$ edn.). South African National Roads Agency Limited. Pretoria, RSA.

SAWB (1956) Climate of South Africa. Part 3: Maximum 24-hour Rainfall. South African Weather Bureau Publication WB 21. South African Weather Bureau, Pretoria, RSA.

SAWB (1992) Climate tables of South Africa. South African Weather Bureau Publication WB 42. South African Weather Bureau, Pretoria, RSA.
SCHULZE RE (1980) Potential Flood Producing Rainfall for Medium and Long Duration in Southern Africa. Report to Water Research Commission, Pretoria, RSA. 37 pp. Report Number??

SCHULZE RE (1984) Depth-duration-frequency studies in Natal based on Digitised Data. In: Maaren H (ed.) South African National Hydrology Symposium. Department of Environmental Affairs and Tourism Technical Report TR119. Department of Environmental Affairs and Tourism, Pretoria, RSA. 214- 235.

SCHULZE RE, SCHMIDT EJ and SMITHERS JC (1992) SCS-SA User Manual: PC-Based SCS Design Flood Estimates for Small Catchments in Southern Africa. Agricultural Catchments Research Unit Report 40. Department of Agricultural Engineering, University of Natal, Pietermaritzburg, RSA.

SINSKE BH (1982) Bepaling van uiterste neerslag vir intermediêre reënvalduurtes in Suidelike Afrika. Water SA 8 (3) 149-154.

SMITHERS JC and SCHULZE RE (2000a) Development and Evaluation of Techniques for Estimating Short Duration Design Rainfall in South Africa. WRC Report No. 681/1/00. Water Research Commission, Pretoria, RSA. 356 pp.

SMITHERS JC and SCHULZE RE (2000b) Long Duration Design Rainfall Estimates for South Africa. WRC Report No. 811/1/00. Water Research Commission, Pretoria, RSA. 69 pp.

SMITHERS JC and SCHULZE RE (2003) Design Rainfall and Flood Estimation in South Africa. WRC Report No. 1060/01/03. Water Research Commission, Pretoria, RSA. 155 pp.

SMITHERS JC and SCHULZE RE (2004) The estimation of design rainfall for South Africa using a regional scale invariant approach. Water SA 30 (4) 435-444.

VAN DER SPUY D and RADEMEYER PF (2008) Flood Frequency Estimation Methods. Proceedings of Course: Flood Hydrology. University of Stellenbosch, RSA.

WEDDEPOHL JP (1988) Design Rainfall Distributions for Southern Africa. Unpublished M.Sc. Dissertation, Department of Agricultural Engineering, University of Natal. Pietermaritzburg, RSA. 
http://dx.doi.org/10.4314/wsa.v37i4.4 Available on website http://www.wrc.org.za 